\title{
WORK, ECONOMY AND DISABILITY IN THE BRITISH COALFIELDS
}

The period from 1880 to 1948 witnessed considerable economic, industrial and political change, and the coal industry was situated right at heart of the various transformations that took place. At the start of this period, the economy had experienced a number of decades of growth and Britain's worldwide economic and imperial pre-eminence was undoubted. By the end of the period, in contrast, Britain had experienced two periods of total war and a prolonged period of economic depression, and had fallen behind a number of its international competitors. Nothing encapsulated this transformation more than the coal industry, which itself had endured the loss of markets, severe dislocation and profound difficulties. War, international economic turbulence and structural problems in the industry had caused a period of sharp decline in the decades after the First World War and, while nationalisation in 1946 was greeted by miners and their supporters as a new beginning, the coal industry was nevertheless a much smaller industry by that time, as compared to its Edwardian heyday.

The lives and experiences of disabled people were affected in profound ways by these various developments in the coal industry and, indeed, were central to those changes. Numerous pieces of legislation were passed, intended to improve working conditions and safety standards, though with varying degrees of success, while technical innovations such as mechanical coal-cutting and electrification served to introduce new risks into the industry. Injury and disease continued to imperil life and limb, and impairment was the experience of a large number of the inhabitants of mining districts. These impairments had an impact on the ability of workers to earn an income - some miners were permanently excluded from the coalmining economy, their working lives permanently altered - but others continued to work in the industry, albeit in other capacities and with a resultant drop in income. In fact, this is an important theme in this chapter and the study as a whole. Impaired workers have been almost invisible 
in coalmining historiography, and this chapter argues for an economic history of British coal that recognises the centrality of disability. This theme also addresses a central contention within disability studies over many decades, that industrialisation was the major cause of the exclusion of disabled people from the economy in the modern period. ${ }^{1}$

\section{The coal industry, I880-1948}

The history and nature of the coal industry in the period from 1880 to 1948 is the crucial context in which miners and their wives were impaired, individuals were disabled and understandings of disability were constructed. This context needs to be understood before the experiences of disabled people can be properly contextualised. The years from 1880 to the outbreak of the First World War found the coal industry enjoying what N. K. Buxton has called a 'comfortable superiority' at the head of British industry. ${ }^{2}$ Its road to domination was a longstanding process equally informed by national industrial development and established regional economic and geological patterns. Coal production increased from ten million tons of fuel produced in 1800, to thirty million in 1840, 150 million in 1880 and finally 287 million by the eve of World War One. ${ }^{3}$ This increase was matched by a corresponding rise in the labour force, and a little over a million men and boys, roughly a tenth of the entire occupied male population, were directly employed in the industry by that peak year of production in 1913. ${ }^{4}$ Yet these figures belie the enormous regional variations, as individual coalfields developed at varied rates as a result of the different coals found in each coalfield, the various markets for such coals and the particular activities of local industrialists.

The 'Great Northern Coalfield', in Durham and Northumberland, attained a superior position in the late eighteenth century in terms of production, manpower and cultural and political significance, and retained this primacy up until the Edwardian period. Early development had taken place in the Tyne Valley and along the coast, but new collieries came to be opened in other parts of the two counties as the century progressed. ${ }^{5}$ Such was the development that the north-east of England produced almost a quarter of Britain's coal by 1880 and employed a fifth of the industry's labour force, almost 100,000 individuals in total. ${ }^{6}$ The north-east of England was finally surpassed, in terms of output and manpower, by south Wales just prior to the First World War. The deeper pits sunk in the central part of the coalfield to exploit the deeper coal reserves situated under the Cynon, Rhondda and Rhymney valleys from the 1870s onwards meant that south Wales had overtaken the north-east of England. By 1913 it was employing one fifth of British miners, almost a quarter of a million 
men and boys, and producing one fifth of coal in Britain, 56 million tons in total. ${ }^{7}$ The region particularly benefited from an increase in demand for British coal from abroad, as exports rose from a total proportion of less than one tenth of British coal production in 1869 to a third in $1913 .{ }^{8}$

While the north-east of England and south Wales differed in terms of the chronologies of their development, they were nevertheless the two largest coalfields in Britain by 1880 . Scotland differed from these two regions in that there were a number of distinct and separate fields, spread across a larger area than was the case with the more compact fields in the other two regions. Historians refer to two distinct regions of Scottish mining. Both regions were situated in a broad swathe of the country through the central lowlands but can be distinguished according to the East of Scotland coalfield, which included Clackmannanshire, Stirlingshire, Fifeshire and the Lothians, while the larger, West of Scotland coalfield included Dunbartonshire, Renfrewshire, Ayrshire and Lanarkshire. ${ }^{9}$

Following the peak year of production in 1913, the British coal industry faced a period of uncertainty and economic depression. While the First World War increased the economic and political importance of the industry, it also sowed the seeds of the industry's difficulties in the interwar decades. This was particularly the case for exporting regions, such as Scotland, the north-east of England and south Wales, as international customers were lost during the war and those countries found new suppliers or else developed their own coal industries to compensate for the loss of imports from Britain. ${ }^{10}$

The immediate post-war years seemed to herald a period of optimism and buoyancy, with the coal industry still enjoying the benefits of the large orders and full employment brought about by the war, but industrial strife and economic downturn brought such optimism to an end and heralded the start of a long period of mass unemployment. Many collieries closed in that first jolt of recession in 1921, while others succumbed to the worsening economic conditions from 1926 onwards and the worldwide economic recession from 1929. By 1929 a quarter of all coalminers were unemployed and the coalfields of south Wales, the north-east of England and the Scottish coalfields were among the worst-hit regions of Britain, with unemployment rates approaching 40 per cent, twice as great as the level in Britain as a whole. ${ }^{11}$ The performance of the industry improved somewhat from the mid-1930s onwards, while rearmament and then the outbreak of war in 1939 served to increase demand for coal and helped to lessen unemployment. Indeed, the 1940s saw a shortage of labour in the mining industry as demand rose and many miners were drawn into the armed forces. $^{12}$ 
Economic considerations were also crucial to the cultural production and thematic content of coalfields literature. ${ }^{13}$ In the late Victorian and Edwardian period working-class writing on the coalfields primarily took the form of poetry, ballads and some autobiographical works. Poetry and ballads were often sold by the sheet, raising a supplementary income for the miner, with some of the more successful writers being published in collected editions later in life, or posthumously. ${ }^{14}$ In regard to the coalfields novel, most authors in this period were middle class and often interested in religious subjects, particularly exploring Methodist topics in the industrial, working-class community. ${ }^{15}$ These novels, as well as early examples of coalfields (auto-) biographies, ${ }^{16}$ were largely published with the support of Christian publishing companies and by sponsorship from individual Methodist ministers. ${ }^{17}$ In the period following the First World War, coalfields literature flourished as a genre, supported by an increasing number of politically left-leaning publishers, ${ }^{18}$ as well as by developments in education, that afforded opportunities to be published that were not previously available to working-class writers.

Economic considerations were both key to the opportunity to write and a central theme in working-class literature of the interwar period interested in poverty, economic depression and unemployment. The majority of these 'miner-writers' were not employed as miners at the time of writing, and most took up writing following the prolonged industrial action of 1926. This includes miner-writers such as Idris Davies, Jack Jones, Lewis Jones, Joe Corrie and Harold Heslop, all of whom explored the interaction between the economic depression and industrial unrest. Jack Jones gives detailed descriptions of the money he earned from writing and lecturing in his autobiography, Unfinished Journey, but notes he was 'still destitute and entitled to Public Assistance' ${ }^{19}$ under the definitions of the means-test investigator. Jones received $£ 25$ for his first novel, Rhondda Roundabout, but he describes how most of that money disappeared quickly when $£ 5$ had already been spent to pay a typist (initially he could not afford a typewriter) and the rest went to repay part of his debt to his son Glynne, the back-rent and half-year's rates. When a piece of writing, titled Behold They Live, was rejected for being 'too gloomy', Jones raved:

How could it be other than gloomy? A hundred and fifty thousand unemployed for the best part of ten years - many of 'em longer than that. Hanging on to life by the skin of their teeth in narrow valleys where there's damn-all to look at but a couple of derelict pits and the man-made mountain of pit-refuse into which the men and boys of the 'dead' townships burrow for brassy coal to keep the home-fires burning. Gloom, yes, and gloom the world should be aware of. $^{20}$ 
Jones was not alone in articulating a desire to make the world aware of the situation of the unemployed miners; this was a common statement from contemporary working-class coalfields writers. In this way, the economic depression had a significant impact on the underlying theme of much of the coalfields literature, as well as creating the unemployment that encouraged many of these former miners to take up their pens.

\section{Work}

While coalmining was not characterised by the same occupational diversity or variety of grades as other industries, still the types and character of work done by workers in the industry varied. Underground workers constituted roughly 80 per cent of the mining workforce but, here too, there were differences in the types of tasks carried out by different individuals each working day. ${ }^{21}$ Of these, it was the 'hewer' or 'collier', in his work cutting coal at the face, who occupied the top position in the hierarchy of grades in the mining workforce. ${ }^{22}$ Hewers were the largest group of underground workmen and, by 1905, constituted roughly 48 per cent of the total in the north-east of England, 56 per cent of those in south Wales and 59 per cent in Scotland. ${ }^{23}$ Men tended to become hewers in their early twenties, after having worked at various different tasks previously, when their strength was at its greatest. Their work was the most onerous, but it was also the best paid and carried the highest status. To some degree, the precise character of the work of hewers varied from coalfield to coalfield: hewers in the north-east of England carried out less 'deadwork' than their counterparts elsewhere, since they did not, for example, cut, load, remove or set the props that held up the roof underground, whereas the Scottish hewers and the south Welsh colliers generally did most of their own deadwork. This was partly due to geological conditions underground - the more vulnerable roofs in south Wales and Scotland required immediate attention from colliers; it also meant that colliers in south Wales were better paid, but that their cousins in the north-east held a higher status in a more hierarchical labour force, since their work was a little more differentiated. ${ }^{24}$

Elsewhere underground, many of the other grades of workmen were engaged in haulage: 'putters' and 'drawers' pushed trams of coal, while 'hauliers' or 'drivers' handled the ponies or, later, engines that became the main means of transporting drams of coal underground from the late nineteenth century onwards. 'Hitchers' and 'onsetters' transferred the drams to the pit cages for ascent to the surface, while a variety of labourers ensured that the roadways and other areas were kept in working order: 'roadsmen' maintained the roofs and sides of passages underground, while 'bottomers' were responsible for keeping good order at 
the pit bottom. Changes in working methods also necessitated the employment of new types of workers underground: masons and bricklayers were required, for example, as the longwall method of mining coal was adopted and necessitated the erection of walls to channel the flow of air, while mechanisation created a demand for fitters and electricians to service the haulage and coal-cutting machines. ${ }^{25}$ All of this work underground was overseen by colliery officials such as overmen, viewers, deputies and firemen.

Work on the surface tended to be of a lower status than underground work and was less well paid. It was also more heterogeneous than work underground, and a variety of tasks were completed by different types of worker. 'Enginemen' controlled the engine that raised and lowered the cage, while 'furnacemen' shovelled the coal that drove those engines. 'Banksmen' or 'pit-headmen' unloaded full drams from the cage and sent empty cages back down, while 'putters', 'drawers' and 'drivers' moved those drams from the pit-bank to the screens or tippers. The screens were themselves staffed by boys, old men and, in some coalfields, women who picked pieces of stone and muck out of the coal. Other surface workers included blacksmiths, who were needed to shoe pit ponies and also to make and mend the large number of metal objects that were utilised on a daily basis in a colliery, pick sharpeners, horsemen, saddlers, carpenters, waggon fillers and men in the lamp room who filled, distributed and collected the lamps each day.

The one type of surface workman who possessed as high a status as the underground hewer was the checkweighman, who ensured that the coal raised by each hewer was weighed and recorded fairly; checkweighmen were often also prominent trade union activists, since, chosen by the men, they could not be victimised by employers as easily. Therefore, the mining workforce, while not as heterogeneous as those in other industries, was nevertheless varied, and workers found themselves engaged in different tasks each day and faced by a variety of risks and perils in their daily work.

One of the characteristics of the realist coalfields literature was the detailed portrayal of the experience of work at the colliery, including the interactions between different roles. Here the hewer is similarly portrayed as the most prestigious role, even when there are job roles with more seniority, such as the 'firemen' who make decisions about safety. Indeed, 'firemen' are often portrayed as complicit with the management in hiding issues of poor safety from the records, such as not reporting high levels of gas or weak roofs. Tom Hanlin's novel Yesterday Will Return (1946), for example, shows a manager convince a fireman not to report gas, and bribe a young miner who was burned not to say anything, because 'Even if the fireman had not reported the gas, the boy might have claimed compensation for being burned by gas, and that would have meant 
an inquiry and a very expensive business for the Company. ${ }^{26}$ In this way certain roles in the pit were believed to be more aligned with the sympathies of the management, against the interests of the working men. The opposite, of course, was true for a role such as checkweighman, a man appointed by the miners to ensure fairness in the weighing of the coal and their payments. The less prestigious roles were often those performed by boys first starting out in work, by older men no longer able to keep up with the hard pace of hewing or, as we shall see, by miners who had been impaired in the course of their work and could not return to their original underground position.

The daily tasks of workmen clearly varied, and each was impacted differently by the process of mechanisation. Mechanisation was a crucially important aspect of working practices in the latter decades of the nineteenth century and the first half of the twentieth century, and had far-reaching consequences for the risks faced by miners in their daily work. Electric coal-cutting was developed from the end of the nineteenth century, but still only 8 per cent of British coal was machine-cut by 1914 , compared to a fifth in the United States. ${ }^{27}$ The spread of mechanised coal-cutting progressed according to geology and the policies of local companies. In Scotland, for example, difficult physical conditions, which included a largely depleted Lanarkshire coalfield, created a more pressing economic need to modernise, and so spurred efforts to mechanise, while the longwall method of mining utilised in the coalfield also lent itself to mechanisation. ${ }^{28}$ In south Wales, on the other hand, coal was easier to cut by hand and so there was not the same motivation for companies to introduce mechanised forms of coal-cutting, despite the use of longwall methods there too. ${ }^{29}$ Despite this, south Wales developed mechanical conveying at a comparatively faster rate than other coalfields, showing that mechanisation took many forms. ${ }^{30}$ Nevertheless, 75 per cent of all coal was cut by mechanised methods by the late $1930 \mathrm{~s}^{31}$

The introduction of mechanisation, where it was achieved, changed the nature of work for miners and, in a variety of ways, created new risks for miners and increased certain dangers. The 1925 Royal Commission on the Coal Industry, for example, reported on the striking decrease in deaths from explosions and from shaft accidents' in previous years, but noted the increase in industrial diseases. ${ }^{32}$ More significantly, the increased use of mechanised coal-cutting technology and haulage methods served to increase the amounts of dust in the atmosphere and thereby the risks posed by lung disease. In a series of investigative articles on the perils posed by dust, the News Chronicle attributed an increase in silicosis in the mining industry to mechanisation. An article entitled 'When Men Grow Old Too Soon' maintained that 'The alarming increase in silicosis 
is largely due to the mechanisation of boring. ${ }^{33}$ Mechanisation, therefore, had its role in creating injury as well as in preventing it.

Coalfields literature often picked up on mechanisation as a threat to men's health because of the new dangers it introduced. A new coal-cutting machine reduced the hard digging work, recalls Bert Coombes in These Poor Hands (1939), but added danger because the noise drowned out the subtle sounds of a weak roof about to collapse, while the timbers had to be set further apart to allow room for the machine. Coombes was trained to work one of these machines and describes his initial reluctance because 'the work was reputed to be very dangerous, even among men who had spent a lifetime in danger. ${ }^{34} \mathrm{He}$ details both minor and major risks of being near the machine: 'the falling coal and clod, the tearing chain, the bursting cable, and the danger of that amount of electric current made every day's work full of risk. ${ }^{35}$ Following a particularly bad roof fall onto the cutter, it is assumed Coombes must have been buried and one colleague runs straight past him on his way to get help because he 'was so frightened that he did not recognise me. ${ }^{36}$ Coombes comments on how these accidents linger in the mind: 'these near escapes make us nervous for awhile $[s i c]$, especially if we think what might have happened. For some time we see a danger in every stone, then become hardened again. ${ }^{37}$ In one particularly disturbing narrative, in which he describes becoming trapped between the cutter and the roof, the traumatic nature of these incidences is clear:

Already I could feel the pressure on my feet increasing, and I knew that even at that slow speed I would be under that lower part in two minutes, and all my body would have to go through a space that was only four inches in height. I screamed again and again, and struggled, but failed to get loose. [... ] I was frantic with fear, for I could almost sense my bones being crushed under the top. ${ }^{38}$

Fortunately, his struggles knocked a sledge-hammer into the cutter chain, causing the machine's electrics to cut out. Coombes remarks how this incident stayed with him, that he never again attempted to crawl over the top of the machine and that he 'kept that sledge-head for some years after; it had the marks of the picks driven into it. ${ }^{39}$ Bert Coombes was by no means the only writer to focus on the hazards of the new machine. Lewis Jones includes a story of a young man losing his arm to a conveyor in his novel Cwmardy (1937) and Sid Chaplin describes a man's horrendous injuries after falling into the path of a cutter in The Thin Seam (1950). ${ }^{40}$ A recurrent theme is the danger posed by the pressure to speed up and cut corners, particularly in the vulnerable conditions, following the 1926 lockout, in which men 'slaved their navels to their backbones with those damned conveyors grinding at their heels. ${ }^{41}$ One man pushing himself 
to the new, faster pace goes 'giddy' and falls into the machine, losing his arm as a consequence. In a less dramatic but more insidious example Durham miner and writer Sid Chaplin suggests that the need to feed the machine outweighs consideration for the worker's body. The worker, Daniel, is in perfect synchronisation, like a machine himself: 'Dig in, draw out, shoot forth, back, dig in, draw out - the big beautiful machine perfectly serving the other big beautiful machine. ${ }^{42}$ But the vulnerability of the human body is clear, since Daniel is working on, despite a partially broken shovel that promises a 'beat hand' (a condition discussed below $\left.^{43}\right)$ :

Daniel was living up to the canons of the pit: dinna be soft. Now, if it had been me I'd have thrown that shovel with its broken crutch into the goaf, and gone in search of another. That would have meant holding the cutter up for ten minutes or a quarter of an hour. But my hand means more to me that a ten minutes' delay. Or does it $?^{44}$

As with the other literary examples, the introduction of machinery is seen as a benefit for the company, but to the detriment of men's safety.

Different methods of working the coal, whether longwall or versions of 'pillar and stall', by mechanised means or by hand, had important consequences for the organisation of labour underground, industrial relations and levels of union militancy, as Martin Daunton has shown. ${ }^{45}$ In addition, they determined how workers in the industry were paid. Those men who worked at the face and cut the coal, whether described as 'hewers' or 'colliers', were paid piece rates, and thus their weekly wage was determined by the amount of coal they raised. This was crucially important to their experience of work and to the possibility of disability, though the consequences of this method of payment for injury, disease and impairment were complex. On the one hand, piece rates could work to encourage a faster pace of work that increased the risks of injury and impairment to the individual miner. Certainly some socialists and trade union activists laid a great deal of blame for increased risk at the door of the piece-rate system. One socialist newspaper in south Wales referred to the 'infernal bustle of the piece-rate system' in the period just before the First World War which, it claimed, was responsible for 'the tendency towards increased periods and possibilities of bad health and of shortening the length of life of the average miner underground, ${ }^{46}$ Labour MP John Swan wrote against both the piece-rate system and cavilling in his novel The Mad Miner (1933), claiming:

Some day an enlightened public conscience will abolish this iniquitous piece-system in mines and give a measure of justice, by a reasonable daily wage, to the miner whose labour is so arduous whose risks are so great and labour so valuable. 
Piece work and cavils ${ }^{47}$ in mines are vices exploiting virtue. It is an alluring gamble which lends colour to its wickedness. It is an ingenious device and artifice to exploit the innocent helpless miners. It oscillates not only with the good and bad place, but brings the inevitable reaction of risks, accidents and premature age. The strong yesterday are weak to-day and cast aside. ${ }^{48}$

Using the well-worn image of the 'big hewer', Swan shows that even a very strong man would be unable to earn enough wages when working in a very poor, wet and hazardous section of the pit. In comparison to the 'big hewer', less fit men would be even more disadvantaged by drawing a bad lot. Enjoying the benefit of drawing a good lot is therefore cast as a bribe, an 'alluring gamble', to undercut the fight for a fairer minimum wage that goes against the wider interests of the miners and solidarity in the community. By the interwar period, such analysis of the effects of piece work underpinned union critiques of various aspects of the work process and resolutions were passed in favour of its abolition. $^{49}$

On the other hand, and acting against this tendency towards an increased work pace, faceworkers did not work rigidly observed hours, or else missed days when the need or the desire arose precisely because they were paid by piece rates rather than by the hour. John Benson makes the point that while miners in the nineteenth century tended to work regular hours, needed to work hard to earn a decent living and were tied to set periods for ascending and descending the shaft, they nevertheless were more free to vary their working hours than other grades of workmen, who were paid by the hour and who worked set hours. ${ }^{50}$ In his evidence to the Royal Commission on Labour in 1892, for example, the Ayreshire miners' leader Keir Hardie noted that 'The miners, with the exception of one very large colliery, are free to leave the pits when they please ... They are free to go when they please, irrespective of what they have accomplished. ${ }^{51}$ In addition, as a result of the piece-rate system, miners tended to increase their output before holidays or in readiness for some period of greater need, but also lessened their productivity through less intense activity or even days off work when conditions were good. This presented a potential degree of flexibility for disabled workers who could not maintain regular, high productivity - issues of reduced productivity would not have affected their chances of employment because they would have been paid based only on what they had produced, but they would have come up against the commercial imperatives of colliery companies to maximise productivity in order to boost profits.

Voluntary absenteeism was common and, at times, faceworkers opted for greater leisure time rather than larger incomes when a certain standard had 
been achieved. ${ }^{52}$ This tendency, however, was probably more true of the period up to 1914, when buoyancy in the trade was more marked, than was the case during the years of the two wars or the interwar economic depression, when various pressures served to limit the amount of autonomy that workers were able to exercise in this context. At the same time, and crucial to the social history of disability in the coal industry, it is evident that voluntary absenteeism came to form a strategy for impaired workers in their attempts to manage their failing strength and the effects of occupational disease. The miner-writer Bert Coombes looked to defend his comrades from accusations that their absenteeism imperilled the war effort in the 1940s and asserted that many miners missed a shift or two each week as they felt their chests tightening as a result of pneumoconiosis: they 'hope to stave off the disease by losing time frequently and so clearing the lungs ${ }^{53}$ In such instances, well-being and physical capacity were prioritised over additional income in the piece rate-system.

Not only did the organisation of work in a colliery have consequences for the form of payment made to coal workers, but it also determined the shift patterns and working hours in the different coalfields, which themselves were crucial to the work experience and the likelihood of disability. Until the Mines Regulation Act of 1908, hewers in the north-east of England worked one of two short shifts each day, either between $4 \mathrm{am}$ and about $11 \mathrm{am}$ or else from $10 \mathrm{am}$ to about 4pm. Their 'bank-to-bank' time (the time from pithead to pithead) was roughly six-and-a-half hours, while their time at the coalface was about five-and-a-half hours, giving them relatively short working hours in comparison with other types of workers and to other miners. ${ }^{54}$ In contrast, and due to the longwall system utilised there, colliers in south Wales worked one long shift during the day. Efforts had been made during the nineteenth century to persuade workers to adopt the two-shift system, but, careful of their family lives and domestic arrangements, and keen not to share their stall with another miner, they had refused. The result was that by the early twentieth century south Wales colliers spent almost ten hours bank-to-bank and roughly eight hours at the coalface. Daunton has calculated that when short days are also taken into account the disparity between the north-east of England and south Wales was even more marked and that miners in parts of south Wales worked 48 per cent longer than their counterparts in the north-east. ${ }^{55}$ Colliers in south Wales continued to work longer hours than miners in other coalfields by the time of the First World War, despite the 1908 legislation that supposedly brought the working day down to eight hours. ${ }^{56}$

The differences in working hours between different coalfields explain the varied responses to the campaign to bring about statutory working hours in the coal industry. Through much of the latter part of the nineteenth century, 
coalminers' leaders, similar to union leaders in other industries, had campaigned for the introduction of an eight-hour day in the industry. Many Scottish miners, notably those in Fife, had gained an eight-hour day in the 1870 s, and so any such change meant less to them than it did to miners in coalfields such as south Wales, where the introduction of such a measure would have made a material difference to their daily working lives. ${ }^{57}$ In Durham and Northumberland, by contrast, an eight-hour day would have meant an increase in hours for many miners. In 1906, 74 per cent of miners in the north-east of England were already working fewer than eight hours a day, while in south Wales the number was 0.4 per cent. $^{58}$

In the debates over the appropriate numbers of hours that miners should work, it is interesting to note that safety, injury and impairment played a role. ${ }^{59}$ In discussions over an eight-hour day in the 1890s, for example, can be found the assertion from miners' leaders that accidents that caused deaths and disabling injuries were higher in the last hour of work than in any other part of a shift. In addition, coalowners' representatives asserted that accident rates were higher in the earlier parts of shifts and that the faster winding of men that was necessary to ensure that no individual worked more than eight hours would increase the chances of winding accidents. ${ }^{60}$ A ballad composed in the 1890 s as part of the campaign insisted:

Yn nghanol awyr afiach

Drwy'r dydd mae'r Glowr hy',

Ac yn ei amgylchynu

Y mae peryglon lu;

Llefaru'n nghlust y Collier

Mae Iechyd teg ei wawar,

'Rho'r Sledge a'r Mandrel heibio

Ar ben yr Wythfed Awr.'

\author{
Down 'midst foul air and gases \\ The Collier works all day, \\ And many are the dangers \\ Which ever round him stay; \\ But, hark! He hears a whisper, \\ From Health it now does come:- \\ Throw down the sledge and the mandrel \\ When Eight Hours' work is done. ${ }^{61}$
}

A seven-hour day followed in 1924, but was swiftly suspended by the Coal Mines Act two years later; again, disability figured in the discussions over working hours. In this instance, opponents of the reduction in hours argued that they would cause more accidents and disabling injuries, since piece-rate workers would be inclined to rush their work in order to earn the same sums of money. The Colliery Guardian, mouthpiece of the coalowners, opined that it naturally follows that the last hour may indeed be the most dangerous, for in it the miner may be attempting to bring up his "darg" to the appointed standard'. An eight-hour day would allow the miner to 'work more leisurely or there will be fewer men employed; in either case, the exposure to risk will be reduced'. Their 1926 article also argued that the miner needed the first hour to 'get into his swing.' ${ }^{62}$ 
As we have seen, faceworkers were paid piece rates, and so had unconventional working patterns or did not work set hours. This meant that they were able to manage their work practices and intensity a little better than other grades of workers, who, paid flat rates, were more likely to observe set working hours. The particular organisation of work in each colliery and coalfield also influenced the working hours of other underground workers. As far as haulage workers were concerned, for example, hauliers in south Wales worked shifts of similar length to colliers, whereas haulage workers in the north-east of England were required to work a long shift to cover the two daily shifts of the hewers. The result was that they worked roughly half as much again as the hewers they served. ${ }^{63}$ There was a certain irony in this pattern for impaired workers, since hewers who suffered an injury or an occupational disease were often moved to 'light work' (discussed in detail later in the chapter) on the surface but then faced longer working hours. ${ }^{64}$

Not usually included in considerations of the mining workforce but still nevertheless crucial to the functioning of the industry (and tellingly prominent in coalfields fiction) were miners' wives, mothers and other female members of their families in the home. The work of boys and men at the pit would not have been possible without a considerable amount of unpaid female labour in the home and, as V. L. Allen commented, 'Wives have been adapted to meet the needs of mining as effectively as the miners themselves. ${ }^{, 65}$ This idea was given articulation by the women's sections of the labour movement in the early decades of the twentieth century as activists attempted to raise the profile of 'women's issues' and so framed the home as a woman's workplace: as Elizabeth Andrews, the women's organiser of the Labour Party in Wales and herself the daughter of a miner and wife of a former miner, stated, 'The Home is the Woman's Workshop. ${ }^{66}$

Similar to miners themselves, while the character of their work was broadly similar from place to place, the precise character of the women's workplace varied from coalfield to coalfield. This was due, in part, to the housing forms utilised in different coalfields, but also, more importantly, due to the age of the housing stock. A large proportion of the houses inhabited by miners' families in the north-east of England, for example, were built in the first half of the nineteenth century, when the coal industry was developing at a rapid rate. The later development of coal communities in south Wales meant that larger numbers of houses were built in an era when bye-laws stipulated certain minimum standards of quality and when sanitary technology was more effective, though the incredible rate of in-migration placed enormous strain on the housing stock and created a housing crisis in the years before 1914 that was not matched in other coalfields.$^{67}$ The experience of Scottish coalfields was different again and, 
while there was variation from one place to another, housing there reflected the inferior quality of housing in Scotland relative to other parts of Britain generally, and was of a very low standard. ${ }^{6}$

Too often, miners' houses were small and cramped, with too little room for the large families that inhabited them. Miners' families tended to be larger than average, since the possibility of men earning relatively high wages by their early twenties encouraged early household formation and resulted in higher fertility rates. ${ }^{69}$ In addition, many mining families looked to ease the burden on household resources by taking in lodgers, while other families sub-let part of the house to another family in the form of 'apartments', which served to increase the overcrowding; in fact, 10 per cent of all houses in the north-east of England and south Wales were sub-let in 1911, and the proportion was on the increase in south Wales at that time. ${ }^{70}$ Indeed, the rapid development of the south Wales coalfield in this period, as well as that of the Fife coalfield in Scotland, meant that housing provision failed to keep pace with population increase in those two places in the two or three decades before 1914, with the effect that occupancy levels exceeded five persons per dwelling. ${ }^{71}$

Scottish MP, former miner and successful novelist, James C. Welsh, highlighted the inadequacies of miners' housing in a speech to Parliament:

I saw a miners' row - about four or five hundred houses, all of them single apartments. There were two holes in the walls for beds. It was certainly a happy home, as happy as it could be made under the circumstances, but in one of the beds lay an injured parent, brought home from the mine, writhing and groaning in agony, and in the other bed lay a dead child, and at night time, during the period of waiting between death and burial, the dead child had to be lifted out to allow the living ones to get in.

It was not because they were thriftless or drunken people, but because economic circumstances were such that they created conditions of that kind, that made it absolutely impossible for human lives to be lived. ${ }^{72}$

Welsh forcefully contrasts this tragic scene with the 'Aladdin's cave of riches ${ }^{73}$ on display in Parliament to argue that such a wide discrepancy is immoral and unjustifiable. Jack Jones, another miner-writer, blamed the poor housing conditions faced by miners in south Wales on the control the 'Company' had over every aspect of coalfields life:

Everything was 'Company' owned and controlled. Schools, houses, doctors, teachers, clergymen of the Church of England, canal, railways, banks, souls. So the Company doctors [visiting cholera cases in Company homes] didn't dare open their mouths too wide about the housing conditions of the place. $^{74}$ 
Both men foreground the health impact of inadequate accommodation and frame poor housing as a political issue.

Individual testimony provides another window on the experiences of individual families of poor housing well into the twentieth century. One of the Durham miners' wives who featured in the Women's Health Enquiry Committee in the 1930s, for example, lived in a cottage that was described in the survey as 'atrocious'. The cottage had two bedrooms, one of which had only a skylight while the other had one small window, the roof was in a poor condition and let in water when it rained, the oven was defective, there was no gas, no bath, no electricity and all water for the baths of her husband and working son had to be lifted onto an open fire for heating before being decanted into a tin bath. ${ }^{75}$ This was not very different to the experience of a large proportion of miners' wives, since colliery houses were rarely equipped with baths; Dot Jones noted, for example, that 'as late as 1920 only $2.4 \%$ of the 26,822 working-class homes in the Rhondda had baths. ${ }^{76}$ It was not until 1926 that pithead baths became a legislated provision, covered by the Miners' Welfare Fund and funded by a levy on royalties, and so the majority of miners continued to bath at home well into the 1930 s. $^{77}$

These houses were the workplace of the majority of women living in the coalfields, and though the age and quality of buildings varied from coalfield to coalfield, the character of the work carried out within the home by wives and other female members of the family was broadly similar across the coalfields. This work, of course, involved servicing the various needs of the colliery workers in the family, and such was the onerous nature of the tasks involved that it was described by one contemporary authority on women's health as 'domestic slavery. ${ }^{\text {, }}$ The preparation of food, the raising of children, the washing of miners' bodies, clothes and boots and the constant cleaning and tidying of the home environment were the daily lot of the miner's wife. Indeed, some historians have noted that the domestic responsibilities of miners' wives, due to the high volume of dirt brought into the home, the larger families and the poor standard of housing, were greater than those of the wives of other types of workers. ${ }^{79}$ In a powerful short story from 1942, in which a miner's wife and mother of five strapping sons is gradually worked to death, the beleaguered woman complains, 'one collier's more work in the house than four clean-job men. ${ }^{80}$

The preparation of the miner's bath was the domestic activity most linked to women's disability by feminist and labour women campaigners in the early decades of the century. This was because the mere act of drawing a bath involved the woman in considerable heavy labour, starting, in many cases, with a walk to a communal standpipe, then the transportation of sufficient water to the home, the lifting of heavy pans of water onto open fires, and then the decanting 
of those heavy pans into the bath ready for the miner to be washed. ${ }^{81}$ Possibly repeated a number of times a day, depending on the number of miners in the family, this activity placed enormous strains on women's bodies and, added to the effects of numerous pregnancies and poor obstetric care, resulted in a significant level of female reproductive impairment. In her testimony to the Sankey Commission in 1919, Elizabeth Andrews, the Labour Party's women's organiser for Wales, stated that:

A midwife of 23 years' experience ... in the Rhondda stated to me that the majority of cases she has had of premature births and extreme female ailments are due to the physical strain of lifting heavy tubs and boilers in their homes which they had to do under the present housing conditions. ${ }^{82}$

Pithead baths, she argued elsewhere, would mean:

shorter hours, less drudgery, dirty work for the women. More rest. More leisure. Less physical strain on mothers. No need for handling and lifting heavy tubs and boilers. Healthier mothers, brighter mothers, cleaner and brighter homes. ${ }^{83}$

The working lives of mining women in the home were, in their ways, just as hard, if not more so, as those of their male family members. In her study of late nineteenth-century Rhondda, historian Dot Jones claimed: 'the mortality rates of women who worked in the home were higher than those of their menfolk who worked in the pit, in direct contrast to national mortality trends. ${ }^{84}$ And yet, such women continued to perform their domestic roles despite suffering debilitating conditions and ailments, and had few means by which to lessen the strain on their bodies.

While the power of the British labour movement, with miners at the heart of matters, was harnessed to bring about statutory limits to working hours, no such campaigns were waged to limit the working hours of miners' wives in the home, despite those wives often working twice as many hours in a day as their husbands underground. One campaigner, the author of the 'Women's Column' in the Rhondda Socialist newspaper in south Wales, pointed out in 1912 that while miners had won their long-sought aim of an eight-hour working day, and that while legislation had been passed to limit the working hours of women in factories and workshops, no such amelioration of the working hours of women in the home was likely. Freedom from 'tiring drudgery' and such 'glaring inequality' was to be achieved only if women themselves took the issue up and if their husbands came to realise that they needed to strive on behalf of their wives as much as themselves. ${ }^{85}$

Part of the problem faced by women labouring in the home can be found in the shift systems of male workers. Since mining households might have two, 
three or more miners (for example, a man, perhaps his brother, working sons and lodgers), a woman might have been confronted with having to service the needs of a number of male workers starting and finishing shifts at different times of the day. In such a situation, the onerous burden of sending the male worker off to his shift and then later preparing a bath, cleaning clothes and tidying the house of the resultant mess and disorder would have been repeated a number of times in the day, with considerable strain on a woman's body. The Women's Health Enquiry Committee found that while the wives of most workers rose at 6:30am, those of miners and bakers were often required to rise at $4 \mathrm{am}$ to see their husbands and sons off to work in the morning; some such wives never had a period of more than four continuous hours of unbroken sleep in any twenty-four hour period. ${ }^{86}$ One Durham woman mentioned in the Enquiry rose at $3 \mathrm{am}$ to get her eldest son off to work, went back to bed and rose again at $7 \mathrm{am}$ to see to the needs of the household and then did not turn in again until $11 \mathrm{pm} .{ }^{87}$ The pattern of shifts was crucial and could cause a multiplication of the workload for any individual woman: Elizabeth Andrews, in her testimony to the Sankey Commission, noted that while there were two shifts in south Wales there was also a third shift for repairers (i.e. $7 \mathrm{am}$ to $3 \mathrm{pm}$, $3 \mathrm{pm}$ to $11 \mathrm{pm}$ and, for the repairers, $11 \mathrm{pm}$ to $7 \mathrm{am}$ ), so that 'It means for a woman who has two sons and a husband working that if they work on different shifts, her life is nothing but slavery. She gets neither rest nor leisure under those conditions. ${ }^{88}$

\section{Mining disabilities}

Work in and related to the coal industry impaired large numbers of individuals and the industry gained a reputation for its considerable dangers and the extensive toll in lives, injuries and ill-health. The dangers posed to mineworkers by largescale disasters received the most attention within the media and were treated in a melodramatic and sensationalist manner, but, in many ways, it was the more mundane, everyday risks that brought about the greatest amount of impairment. In the first place, most accidents happened underground rather than on the surface. In 1920, for example, of the 117,302 individual miners across the entire industry who were injured sufficiently to necessitate seven or more days off work, 91 per cent were injured in accidents underground. Of these 106,730 individuals, fully 41,358 (35 per cent) were injured in accidents involving the fall of materials from the roof or sides underground. ${ }^{89}$ These might have entailed falls involving a few tons of material that had the capacity to kill or maim, or the fall of a single rock that was no less dangerous to any individual miner in its way. ${ }^{90}$ Throughout the interwar period almost a half of all fatalities 
and 'injuries' (i.e. injuries sufficient to disable a man from working for seven days or more before 1924, or three days or more after 1924) came as a result of falls of the roof or sides. ${ }^{91}$ All underground workers, to a greater or lesser degree, faced the risks posed by the possibility of falls of rock and coal, but faceworkers were subject to the greatest risk, since the task of opening faces or 'dropping' the coal increased the instability of the rock and coal strata before the roof and the sides could be supported adequately. Furthermore, geological characteristics underground varied from one coalfield to another, and so the risks faced by miners in various coalfields differed; in 1920, for example, 3,767 miners from Scottish coalfields, 5,875 in Durham and Northumberland and 7,975 in south Wales were injured. ${ }^{92}$ These regional variations are reflected in coalfields literature to a certain extent: mining disasters involving floods are more commonly found in novels set in Scotland and north-east England, ${ }^{93}$ whereas those involving gas explosions tend to be set in Wales. ${ }^{94}$ Specific regional geological features are also central to the plot of certain novels, such as the dangers of a weak blue-shale roof under the longwall system in Harold Heslop's Last Cage Down (1935), or the investigation into the high incidence of lung disease among anthracite miners in A. J. Cronin's The Citadel (1937). ${ }^{95}$

Apart from falls, the other large classification of underground accidents that led to injury and disabling conditions was related to haulage. Whether powered by horses, by hand or by mechanical means, impact and crush injuries caused by trams and tubs were the cause of a great deal of disablement. In the early 1920 s roughly 30,000 underground workers were injured every year to such a degree as to be off work for seven days or more, amounting to 26 per cent of all mineworkers injured for seven days or more in each year. ${ }^{96}$ Shaft accidents were less important but still injured and killed large numbers of workers, while the movement of coal on the surface similarly brought workers into contact with fast-moving and heavy machinery and trams that damaged bodies with ease.

Falls of rock and haulage accidents, whether underground or on the surface, caused impact and crush injuries, largely to limbs - with arms, legs, hands and feet broken - but sometimes to the head and the body. Before the better management of fracture and other orthopaedic cases from about the 1930s, such injuries might have led to recovery, but often resulted in malformed fractures, amputation, permanent spinal injuries or a range of other, less serious but nevertheless debilitating injuries.

In addition to such impact or crush injuries, miners also suffered 'beat' diseases, such as 'beat hand', 'beat knee' and 'beat elbow'. These conditions developed as a result of constant pressure, such as when kneeling or pressing against a hard surface, or through repeated impacts, as when using a pick, and involved inflammation that caused that part of the body to become swollen 
and tender to touch. The affected part of the body would also throb, or 'beat' in the north-east of England, thus giving the condition its name. ${ }^{97}$ The long-term nature of 'beat' diseases made them less visible than other impairments but affected miners' ability to continue their work, their mobility and their quality of life. These occupational diseases, at least as they affected coalminers, were scheduled as compensatable under the Workmen's Compensation system from 1906 onwards, and it is evident from the statistics that there was a constant increase in the numbers of notified cases in the decades that followed, so that, by the late 1930s, there were approximately 6,000 new cases across the industry every year, roughly three-quarters of which were 'beat knee. ${ }^{98}$ One medical authority noted in 1914 that most cases recovered within a relatively short space of time but that some ended in permanent impairment. ${ }^{99}$

Another occupational disease that affected miners and that was scheduled within the compensation system alongside the 'beat' conditions under the measure passed in 1906 was miners' nystagmus. Nystagmus is a condition of the eye caused by work in low light conditions in which the main symptoms are an involuntary oscillation of the eyeball, with resultant vertigo, headaches and nausea, night blindness and sensitivity to bright light. ${ }^{100}$ Bert Coombes suggested that sufferers were marked by their particular behaviour:

I have watched them waiting near the pit mouth until someone comes along who will read the wording on a new notice to them; they fumble their way about the village streets when twilight comes; they rely on their hearing to help their uncertain eyes. ${ }^{101}$

The condition was not curable, nor even treatable, in the period up to the 1940s, but symptoms would often abate with the removal of the sufferer from the circumstances that brought on the condition in the first place. For miners, of course, this meant that the individual was removed from underground work and re-employed on the surface; some were able to continue to work underground after a period in better light conditions, but a greater number were transferred to work on the surface, while others were forced to leave the industry altogether. ${ }^{102}$ Again, similar to the case with the various 'beat' diseases, the number of cases of nystagmus in the coal industry increased after notification was made compulsory in 1906, so that there were roughly 10,000 ongoing cases at any time in the interwar period. ${ }^{103}$ Ascertaining the relative numbers of sufferers in each coalfield is impossible, since the policies adopted by employers and their mutual indemnity organisations or insurance companies determined the numbers of cases certified each year. ${ }^{104}$ Contemporary medical authorities insisted that the disease disproportionately affected faceworkers: of the 685 cases discussed by T. Lister Llewellyn in his review in 1913,81 per cent were employed the 
coalface and only small numbers of other grades of workers were found to suffer the condition. ${ }^{105}$

Perhaps the most notorious of occupational diseases that affected miners, and one that caused massive levels of impairment, was chest disease. A study of miners' chest disease has described it as the 'largest occupational health disaster in British history', and the period from 1880 to 1948 witnessed a transformation in the understanding of and responses to this condition. ${ }^{106}$ Referred to as 'miners' asthma' or 'miners' lung' at the start of this period, classified as 'silicosis' in the early decades of the twentieth century and distinguished as 'coal workers' pneumoconiosis' by the 1940s, the condition was the subject of intense industrial struggles, pioneering scientific and medical research and, ultimately, successful political lobbying that saw it recognised within the compensation system and as a matter of significant government intervention. ${ }^{107}$ Quite simply, the inhalation of coal dust caused the lungs to become congested and damage to be done to the delicate structure of the lungs. The miner himself, at least initially, would become breathless, would suffer coughing fits and would become increasingly fatigued as his aerobic capacity was compromised. As the disease took hold a sufferer would be unable to complete even light manual tasks. He lost weight and assumed an emaciated look, and eventually died from heart disease as a result of the strain placed on the heart.

It is not easy to assess the extent of chest disease among coalminers in the first half of the twentieth century. The changing nature of scientific understanding and medical knowledge, and the changing compensation landscape, meant that statistics are not particularly accurate for the period before 1948. It is also important to note that union, medical and official attention to the condition, at least in the period up to 1948 , was concentrated in south Wales, where the majority of cases emanated from the anthracite district in the western part of the coalfield, despite the incidence of the disease in all British coalfields to varying degrees. According to official statistics, pneumoconiosis caused the deaths of 1,334 south Wales miners between 1937 and 1948, and the permanent disablement of 18,297 others, but the miners' union for the region put the figures at 2,088 and 38,449, respectively. ${ }^{108}$

All those working within the coal industry inhaled some amount of coal dust - the coal-trimmers who loaded the coal into ships at the docks were even found to suffer pneumoconiosis in research carried out in the 1940s - but, again, it was the hewer who suffered this condition more than other grades of workmen. ${ }^{109}$ Despite the presence of dust at all points in the process of raising coal, it was at the coalface that the highest concentrations were found, both because of the dust produced by the work there and also because the ventilation underground tended to be less effective at the extremities of the workings. ${ }^{110}$ 
Moreover, as a piece worker, the hewer was perhaps incentivised to work faster than other grades of worker and, due to the nature of the mining workforce and the character of the occupational trajectory in the industry, he also tended to be younger than most other workers. The effect was that not only were faceworkers affected to a greater degree but the sufferers of pneumoconiosis also tended to be young in age. It was found, for example, that 33 per cent of all sufferers in the Cynon Valley in south Wales in the 1950s were under the age of forty, while the proportion for the neighbouring Rhondda valleys was 26 per cent. ${ }^{111}$ Men in their forties, thirties and even twenties contracted pneumoconiosis and were aged prematurely by the ravages of the disease. ${ }^{112}$ Though hewers faced the greatest risks, Enid Williams found that other categories of worker were also vulnerable. Although an underground labourer's job was lighter than that of a hewer, the work was often dustier. ${ }^{113}$ Williams also found that old and infirm miners, perhaps moved from underground work to work on the screens as a result of impairment, could often face greater dust levels than in any other part of the colliery. ${ }^{114}$ Mechanisation increased dust levels more generally, so that miners in the 1930s and 1940s faced greater dust levels than their predecessors. ${ }^{115}$

While miners were subject to a great many risks and experienced a variety of impairments as a result, they were not the only members of the mining community who faced impairment as a result of the coal industry. The wives and other female family members they left at home each morning to go to work also paid a price for the winning of coal. A great deal of attention in the 1920s and, especially, 1930s, in addition to the focus of historians since that time, was focused on the matter of maternal mortality, but a much greater number of women suffered maternal morbidity and were impaired by the injuries and complications of childbirth; in this sense, the experience of miners' wives mirrors that of their husbands, whose injuries and impairments far outnumbered the more newsworthy fatalities that received the lion's share of the attention. Observers were clear that there existed a large amount of reproductive injury and impairment, even if only a small proportion of it came within the notice of doctors and other health workers. In her important report into maternal mortality published in 1924, for example, Dame Janet Campbell found that ante- and post-natal clinics had begun to reveal the true extent of women's ill-health and debility: 'We find that the expectant mother is often ill-nourished; she is frequently anaemic; indigestion and constipation are accepted as a matter of course; varicose veins and dental caries pass almost unnoticed except perhaps when pregnancy accentuates the aching and weariness of her legs, or causes a more rapid decay of defective teeth. ${ }^{116}$ By the 1930s, when increased attention was being focused on maternal mortality, one 'follow-up' survey of 2,000 
Edinburgh mothers found that 30 per cent of them 'were found to be suffering from various complaints and disabilities which required treatment'. It was noted that such a proportion meant that 'for every mother who dies there are sixty-five others who suffer some impairment of health as a result of pregnancy and childbirth. ${ }^{117}$ Even official investigations were noting the significant toll of impairment that followed on from pregnancy and childbirth: 'But for the relatively few women who die, many are seriously ill, some suffer permanent damage while others are left with some former weakness aggravated and with a shorter expectation of life." ${ }^{, 18}$

The Women's Health Enquiry Committee of the 1930s, the results of which were reported in Working-Class Wives by Margery Spring Rice in 1939, similarly noted that attention had been focused on maternal mortality rather maternal morbidity. Through the completion of a questionnaires by 1,250 women in different parts of Britain, including miners' wives from Durham and south Wales, the Enquiry set out to offer a more complete picture of the character and extent of reproductive impairment. ${ }^{119}$ Spring Rice wrote that maternal morbidity was 'extremely widespread and enduring, so that a woman tends to become progressively less fit with the birth of each child. ${ }^{120}$ Of the 1,250 women who responded as part of the Enquiry, 'gynaecological trouble' occurred definitely in 191 cases and evidence of it appeared in a further 203, but, Spring Rice reported, 'for various reasons no professional diagnosis has been made - the woman herself is ignorant of the cause of her pain or discomfort. ${ }^{121}$ Partly as a sign of this fact, the women themselves described such gynaecological impairments in lay rather than medical ways, as 'uterine trouble', 'womb trouble' or 'internal trouble'. Similarly, an official investigation into the matter in Scotland in the 1920s found that in 10,000 gynaecological cases studied that were admitted to hospital, 65 per cent of women had given birth previously and 28 per cent suffered impairments caused by those previous deliveries. ${ }^{122}$

Miners' wives featured prominently in these accounts of the 'toll of motherhood'. One of the respondents to the Women's Health Enquiry Committee was a thirty-two-year-old miner's wife from Durham. She had been married for fifteen years and had seven children, the eldest of whom was fourteen. Her family lived in a colliery house with an open ash-privy at the back, a damp back bedroom, no sink under the tap, and a coal-house and an ash-pit at the back of the house. Ashes and coals had to be carried through the sitting room, which was itself used as a bedroom and did not have windows that opened. She rose from bed at $4 \mathrm{am}$ and then retired to bed at the end of the day between $10 \mathrm{pm}$ and midnight. Her home was described as clean, her children had never been ill, their diet was varied and good and the health visitor described her as 'an amazing woman, with indomitable pluck'. All this effort, in such conditions, 
came at a cost to her health; she suffered: neuritis as a result of the heavy work of 'possing' (i.e. washing clothes in a tub with a 'poss stick') and mangling clothes; pyorrhoea, for which she had had all her teeth extracted; problems with her kidneys as a result of Bright's Disease; headaches and biliousness; cystitis as a result of pregnancy; and pain in her right side as a result of menstrual periods, 'due to ovarian trouble.'

Another miner's wife in the same coalfield, 'Mrs. D. of Durham', had six children and faced terrible housing conditions, with no bathroom or scullery or indoor sink. She suffered from inflamed eye, 'bad rheumatism', decayed teeth and a prolapsed uterus. ${ }^{124}$ In south Wales, 'Mrs. Y... has five children of whom the eldest is $4 \frac{1}{2}$. As her only difficulty she says, "I have had children too quickly after each other and with young children they take up all my time. Am unable to breast feed". The Health Visitor says "Mrs. Y. looks in very poor condition, she says she always feels tired and disinclined to do anything. I think she was probably anaemic before marriage and five pregnancies in five years have drained her vitality."' 125 Thus, the unsatisfactory working condition of miners' wives, the strain of attempting to cope with such onerous burdens and the effects of numerous pregnancies in quick succession resulted in a high toll of impairment for miners' wives, perhaps a higher toll than their husbands experienced in the notoriously dangerous coal industry.

\section{Employment of disabled people}

The impairments of mineworkers were many and varied, but it would be a mistake to think that these necessarily caused their exclusion from the industry. Throughout the period, impaired individuals found work both underground and on the surface. Certainly, large numbers of such people were excluded from work in the coal industry in a variety of ways both deliberate and systematic, especially when the state of the economy or other factors gave the employers an advantage in the labour market. Nevertheless, large numbers of people were not disabled from working in the industry as a result of their impairment and remained an important part of the labour force, with opportunities, even if they were limited, for work in certain parts of the industry.

Disabled individuals were employed in the coal industry in a variety of ways throughout the nineteenth century, but the systems of statutory compensation which emerged in the late nineteenth century, and which form much of the discussion of the second chapter of this book, were crucially important. The first of these was the Employers' Liability Act in 1880, which recognised employers' responsibility for accidents in the workplace and was superseded by the more encompassing Workmen's Compensation Act of 
1897, which led to the first major system of state compensation for injury and disease. However, in the first place not every disabled person in employment after 1897 came within the remit of the compensation system. While not typical of the experience of most disabled people in the coalfields, many miners completed lifetimes of work underground with a congenital disability, or one which did not arise from their work. An example of the former was Thomas Sharrock, a blind miner who worked in Pemberton, Wigan. His story made it to the Dundee Evening Telegraph, which honoured Sharrock for his thirty-year career as a 'hooker-on' and 'putter', key underground jobs. The story used the 'overcoming' trope that 'his infirmity has not debarred him from participating in some life', including being Grand Master of his local Oddfellows. ${ }^{126}$

In other instances, miners hid the fact or extent of their impairment in order to avoid the unwanted attentions of a manager, or else to convince a potential employer of their employability. One miner, described as a 'cripple with a stiff leg', remembered how he attempted to conceal his impairment: 'Well, if you walk along the top of the P. D. "Pit" with your hands in your pockets they will make you pull them out, and look at them and when they see me walk stiff they won't give me a start.' Miners with hidden impairments also cropped up in accounts of accidents in Inspectors of Mines' reports. For example, the 1913 reports of W. Walker, Inspector of Mines for the Scotland division, noted a series of deaths that year from railways, sidings and tramways. 'Three of the persons killed suffered from physical disabilities', his report noted, 'one being very deaf, one blind in one eye, and the other old and infirm.' The report concluded by relating their disability to their area of employment: 'Such persons should not be employed in places where there are moving wagons. ${ }^{127}$ Whether these workers concealed their impairments from the colliery company or whether the company itself employed these men in contravention of the rules, a certain deception had taken place in these instances, and disabled miners passed as non-disabled.

Apart from miners with congenital impairments, and apart from those who concealed an impairment from colliery officials or the mines inspectors, another group of workers were perceived as impaired and were disabled by the attitudes others held of them. This attitude was summarised by Henry Barnett in his 1909 work, Accidental Injuries to Workmen:

The workman may be physically fit to earn the same wages as before the accident, but may not be able to obtain employment in consequence, say, of the loss of two or three fingers. The disinclination of employers to give work to maimed and mutilated men is well known. There is here a loss of wage-earning power if the inability to work is due to the injuries. ${ }^{128}$ 
Instances involving congenital or concealed impairments are, by their nature, impossible to quantify, but they clearly existed in the industry and were the experience of a certain number of the inhabitants of coalfield communities. Far more visible, industrially, politically and medically, were the workers who came within the remit of the workmen's compensation legislation first passed in 1897. Indeed, that piece of legislation and the numerous subsequent amendments to it were crucial in determining the attitudes of employers, government and the medical establishment and, more importantly, the experiences of disabled miners. It might even be argued that while the First World War and the fate of disabled veterans were crucial to changes in the understanding of and responses to impairment in British society more generally, it was the workmen's compensation legislation passed a number of decades earlier that was transformative for the inhabitants of industrial communities. ${ }^{129}$ The legislation shaped experiences, helped to define notions of normalcy and disability and determined the industrial relations of impairment.

Both before and after the 1897 Act, some workers adjusted their working practices upon becoming impaired, came to rely on the support of workmates a little more or else accepted the reductions in their productivity and income that the impairment entailed. Such workers did not often come within view of employers, unions or any other agency but were present in the industry. More obvious were those individuals so impaired that a more significant change needed to be made to their working lives. Under the regime of the compensation legislation such men were termed 'partial compensation men' and 'partially disabled', since they were sufficiently impaired to be prevented from continuing their previous roles, but not so impaired as to be prevented from working altogether, and were shifted to 'light work' in the colliery. In such 'light work', they earned an income, albeit less than the one earned in their previous role, but were also paid a sum of compensation to reflect, at least partially, their reduced earning capacity. Each miner was unique in the character of the impairment they experienced and the subsequent employment trajectory they followed as attempts were made to match their 'light work' to their particular impairments (though, of course, employers had varying degrees of flexibility, or indeed none at all). This provision is evident in the miners who came within the remit of the Scottish Coal Workers' Compensation Scheme. For example, James Dalrymple, who had contracted miners' nystagmus, was considered 'fit for work on the surface', but anything underground would have caused 'aggravation' of his condition. ${ }^{130}$ Another miner, Charles Robertson, with a strained back, was deemed by the medical referee to 'never be fit for face work' again and 'not fit to walk far underground'. Robertson was instead posted to work at the 'picking tables', sorting coal, while also receiving partial compensation. ${ }^{131}$ 
Sometimes light work could be provided after an extended period away from the mine. Samuel Edmunds, a miner from Penrhiw-Fer, Rhondda, recalled the situation of his father:

Dad had his hand off, left hand, in the mines with the tram. He was a haulier and lost his hand. There was no compensation as such in those days, but he did get twenty-five pounds for the loss of his hand. He was brought home. I was in the house at the time, this was around 1901. They took him to hospital to have it off. As he couldn't go back down the pit at that time, he bought two horses and a brake and after getting a licence from the Council he started as a brake-driver, out all day collecting people from the train station. Take them home he would, Dinas Station to Pen-y-graig. Then he'd take boozers home from the pubs. Fridays, Saturdays, he always got paid, he always got his fare even if they were laugh-drunk. When the trams came about 1910, his business was done away with. He had to go back to the mine. They gave him a light job underground. ${ }^{132}$

That job was to help put dust alongside the roads underground, intended to help prevent explosions. The father died at fifty-seven, 'they said it was asthma then, but now they know it's silicosis. ${ }^{133}$

The numbers of men employed on 'light work' demonstrate the continued and active participation of disabled people in the workplace; but, while the retention of work in the industry would have been welcomed in many cases as the best option for the individual from an economic point of view, it also brought problems for many men and they faced new difficulties in their altered situation. Most of these problems came from the scrutiny of employers and their medical appointees in the compensation system, and the pressure they applied to these 'partial compensation' men. Thus, when the Scottish brusher Kenneth Sparling started his new job at the picking tables, his doctor thought 'he might be able to do a little more if he were trying, and if he were forcibly extending and moving the contracted fingers. ${ }^{134}$ In another example, Matthew Glass, a hewer at Hetton Colliery near Durham, had his left leg amputated after being knocked down and run over by a set of tubs at work. He took up 'light work' sorting coal on the belts, but when he 'could not manage' the colliery management refused to pay full compensation. ${ }^{135}$ Medical Referees certified that he was able to work as long as his artificial limb was of sufficient quality. Though he was not able to work at the conveyor belts sorting coal, the Referee suggested that 'he could ... carry on such work if he were provided with a seat or he could undertake a gate man's job or work in the lamp cabin. ${ }^{136}$ In such instances, therefore, the transition to 'light work' could involve real difficulty and new problems that had to be negotiated. Some attempt was occasionally made to ease an injured man's return to work, but the nature of these industrial workplaces proved disabling in many instances. ${ }^{137}$ 
Undoubtedly, the question of returning to work was a complex experience for recently impaired miners and some were quite clear that they did not wish to return to their former jobs but, instead, would prefer some other employment of 'light work' or else the payment of full compensation. The interplay of these factors was seen in 1926, when the Ocean Coal Company won a case at Pontypridd County Court against a miner who had lost his eye in the pit. The miner was fighting for the right to refuse to return to work 'on the ground that he had a genuine fear that if he went underground to work at the face, he would lose the sight of the remaining eye and thus become totally blind. The court ruled in favour of the company, thus denying the miner compensation and forcing his return to the coalface, and the judge noted that 'a one-eyed man is not prevented from following his ordinary occupation below ground. ${ }^{138} \mathrm{~A}$ former faceworker in Fife who had lost the vision in his left eye took up a job as a roadsman and repairer in 1926, having been 'unwilling to work at the face':

he had been able to adjust himself fairly well to his altered circumstances and to do that work, but ... he found difficulty in judging distances, particularly in low places, and had not the same confidence in moving about, or the same readiness in his work as formerly ... that his main reason for declining to return to the face was that injuries to the eyes were more liable to occur than at roadsman's or repairer's work, which was the case, and if he received an injury to his right eye such as he sustained to his left, he would be practically blind for life. ${ }^{139}$

The miner fought against the decision of face work as 'suitable employment', which was eventually agreed. Yet, overall, the Colliery Guardian article argued that 'as a rule [the one-eyed miner] is able sooner or later to return to his work at the face, providing the remaining eye is sound and its vision normal. ${ }^{140}$ In another case, a miner with a crushed middle finger was declared 'fit for his former work as a miner' but 'refuse[d] to start' at his old position underground and has 'caused the greatest possible trouble in this case'; the company proceeded to 'terminate the right to compensation. ${ }^{\text {,14 }}$ Bert Coombes describes the experience of returning to work too soon after dislocating his knee joint trying to free it from under a collapsed pit roof, due to the inadequacy of the compensation he received: 'They had a way of assessing our earnings and paying an amount that was roughly about half of what I would have earned if working. So to add to my suffering I had the misery of knowing that we were going behind financially; therefore I could not afford to stay in the house until I had recovered.' He was injured in the same, vulnerable knee in the first week back: 'That caused me to have another seven weeks at home, and the insurance people were quite convinced that I enjoyed getting knocked about. ${ }^{142}$ These examples show the complexity of any return to work for impaired miners. On the one hand, they show that 
some injured miners had the opportunity and the desire to return to their former jobs or to other roles in the industry, but they also demonstrate the fears, risks and difficulties that a return to work sometimes involved.

Such illustrative examples are instructive, but they conceal the broader factors that influenced the likelihood of success in gaining 'light work'. The extent to which impaired individuals were able to find work or to retain employment in the coal industry was determined by a number of broader considerations far beyond their control. Two factors in particular conditioned attitudes towards the employment of impaired workers and influenced their chances of gaining or retaining employment: the workings of the statutory system of workmen's compensation and changes to it over time, on the one hand, and the state of the economy and the fortunes of the coal industry, on the other hand. Notwithstanding the responsibility, and economic sense, of companies providing 'light work' to men impaired in their own employment, the system of workmen's compensation instituted by the legislation passed in 1897 made the employment of impaired workers far less attractive to new employers, since it was believed that such workers posed a higher risk of accidents. It was feared that old, unfit and impaired workers would serve to increase compensation liabilities because of their greater likelihood of suffering or causing accidents. ${ }^{143}$ This belief was clearly evident in the decisions of many employers to discard 'old and infirm' miners in the wake of the passage of the 1897 Act. The legislation was implemented in July 1898 and, almost immediately, something like a thousand workers in the south Wales coalfield lost their employment. ${ }^{144}$ One trade union official in the region described the employers' action as 'tyrannical' and maintained that 'These men had spent their strength, their substance, and their lives in the service of the company, and now they were cast adrift on the mercy of the world. ${ }^{145}$

This action on the part of the coalowners in south Wales does not seem to have been replicated in the other coalfields at this time. Industrial relations were particularly poor in south Wales, far more so than in the north-east of England, where a joint Arbitration Committee was established by coalowners and trade union representatives to hear and decide cases that would otherwise have been submitted to the county courts. ${ }^{146}$ That is not to argue that this pressure on the employment of impaired workers was absent from regions other than south Wales. In 1912, for example, managers at the Consett Iron Company in Durham wrote to the under-manager of its colliery at Chopwell to inform him that he needed to dismiss a certain number of workmen and it was old and impaired workers who were to be selected for dismissal: 'There is a decision made to retire men that are considered "useless" - taken mainly from the aged or infirm working at the Pits, in an attempt to reduce the number of employed in "off-hand" labour. ${ }^{147}$ 
Nevertheless, despite such instances, and despite the variations in practice between coalfields, the generally buoyant state of the coal industry in the period up to 1914 meant that opportunities for impaired miners were not completely absent. The precise number of opportunities, and the character of the work that was available to them, varied from place to place and over time. The daily working requirements of a colliery determined the numbers and grades of workmen required to produce coal, and there was perhaps a finite number of 'light employment' positions to be had at any one colliery. Angela V. John has found, for example, that women surface workers were seen to be 'usurping the rightful jobs of [disabled] men. ${ }^{348}$

The situation in the decades after 1914 was far more complex. The workings of the compensation system, in addition to a more difficult economic context and strained industrial relations, all had a bearing on the experiences of disabled workers in the coal industry. This complexity was evident in the First World War. Upon the outbreak of war, large numbers of men left the coal industry to enlist in the army, with 313,000 miners signed up by February $1916 .{ }^{149}$ Despite some initial uncertainty in the industry as it adjusted to different market conditions, the demand for coal grew during the course of the war and was crucial to the war effort. Indeed, the coal industry became a reserved occupation and miners, especially faceworkers, were discouraged from enlistment and, later, exempted from conscription. There was no official policy within the industry, or emanating from government, to replace workers in the industry with impaired ex-miners, and so very little direct reference to the practice can be found. Nevertheless, the pressure of labour shortages led employers to draw upon the reserve army of disabled workers, as they did in other times of labour shortage, and offered the prospect of increased opportunity for employment to men who would have struggled to gain work otherwise. One of the few to articulate the practice was Frederick Mills, managing director of the Ebbw Vale Steel, Iron and Coal Company in south Wales, who stated at a recruiting meeting that 'There was a large number of men available from the surface labour class whose places could be taken by older men, wounded men, and men who had gone into retirement, but who had come out to take their share." ${ }^{150}$

With military conscription in 1916 and, more especially, 'comb-outs' ${ }^{151}$ of the coal industry from 1917 onwards, the opportunities for impaired workers increased and larger numbers were absorbed by the industry. A comb-out of the coal industry in the early part of 1917 , for example, focused on three classes of workmen, one of which was unskilled surface workers, which would have multiplied the opportunities for employment for impaired workers since these were typically the types of jobs done as 'light work' under the workmen's compensation system. ${ }^{152}$ Another of the three categories of workers that were 
to be subject to this comb-out were workers who had entered the industry since August 1915. The military authorities were convinced that many men had entered the coal industry, as a protected industry, in order to avoid being conscripted, but trade union officials pointed out that this group of workmen also included former miners who, suffering the effects of an injury or an occupational disease, had left the industry for some time in order to recover or else had pursued another calling as a result of impairment but had been forced back after their ventures had failed. William Brace, representing the Home Department in a meeting with members of the executive committee of the Miners' Federation of Great Britain (MFGB) in February 1917, but drawing upon his own mining background, pointed out the ways in which such men returned to the industry in this period:

a man may have nystagmus, or he may have asthma, and instead of going on light employment, or working on the surface of the pit, he may go to a little shop, say a barber's shop, or something like that, and give himself a chance to recover. That is the type of man I have in mind. You and I know scores of men of that character. $^{153}$

In that same meeting Williams Abraham, representing south Wales on the MFGB deputation, and William Straker, from Northumberland, also mentioned men who worked as insurance agents. Such movement out of and then back into the coal industry would have been true of other periods of time, but the dislocation caused to the economy by the First World War might have been sufficient to force or entice such individuals to return to the industry in greater numbers at that time.

Comb-outs of the coal industry were focused on particular classes of workmen and avoided the conscription of faceworkers, who were crucial to hopes of increasing production, but, in doing so, faced the law of diminishing returns. This was, of course, because such surface work tended to be filled increasingly by disabled workers during this period. Indeed, by April 1917 James Winstone, a miners' leader from south Wales, opined that a further comb-out of surface workers would have been futile and that something approximating 70 per cent of all such surface workers in south Wales were medically unfit for service in the armed forces. ${ }^{154}$ Robert Smillie, president of the MFGB, estimated that only one in four of all men returned to the military as a result of comb-outs were fit to serve, thereby again demonstrating the extent to which impaired workers had entered the industry in large numbers during and as a result of the war. ${ }^{155}$ Apart from impaired workers who came back into the industry during the war years, some injured soldiers were also placed in the coal industry after a period of convalescence so as to free up other men to join the armed forces. 
This, according to the Northumberland representative on the Executive Committee of the MFGB, J. Cairns, was the practice in his district, and he estimated that there were as many as twenty such individuals in some pits in the area. ${ }^{156}$ Therefore, there seems to be good reason to believe that the opportunities available to impaired workers for employment in the coal industry increased during the First World War and that large numbers either returned after being invalided out of the industry previously or else remained after a point when they would have been forced to leave the industry at any other period.

The interwar economic depression, however, changed the context in which disabled workers sought to retain or gain employment and, generally, served to make the retention of work more difficult. The large ranks of the unemployed meant that employers were given an advantage in the labour market and were able to actively choose between workers rather than merely accept the men that were available to them. In the context of the workmen's compensation legislation and contemporary ideas about efficiency and productivity, impaired workers found it difficult to defend their place in the labour market. In addition, economic depression lessened the numbers of possible vacancies for partially disabled men to fill, since not only did many collieries close, but many others worked short time, possibly two or three days in the week, or else witnessed the closure of one or two districts underground, with a resultant decrease in the labour force. As the labour market contracted, so the opportunities for 'light work' suitable for partially disabled men lessened. This was also exacerbated by the process of mechanisation, since it greatly altered the working practices on the surface and reduced the need for labour relative to the amount of work done. ${ }^{157}$ In a discussion in the House of Commons in 1938, for example,

Mr George Hall asks Minister of Labour whether he is aware of the large number of unemployed miners who are partially disabled owing to accidents received in the course of their employment, and who are now, owing to the prolonged depression, unable to obtain employment in the coal-mining industry. ${ }^{158}$

While disabled miners all faced difficulties during this period of economic depression, the situation was especially marked for miners with nystagmus, since four-fifths of all colliery labour worked underground and these positions were unsuitable for such men; the smaller number of surface jobs offered the only opportunities available to these men. If a nystagmus sufferer was unable to get a job on the surface at his own colliery, the chances of gaining employment on the surface of another colliery were virtually non-existent, since employers tended to reserve such positions for 'light employment men' from their existing workforces. 
More than that, the particular character of nystagmus as a condition meant that sufferers were further disadvantaged, even relative to other impaired men. Some employers, often pressured by their mutual indemnity or insurance companies, adopted an unofficial policy of refusing to re-employ sufferers from nystagmus - certainly this was the approach taken by Lanarkshire coal companies in the interwar period. ${ }^{159}$ The effect was that in September 1936 a greater proportion of miners certified with nystagmus and eligible for partial compensation were unemployed in Lanarkshire than in any other coalfield in Britain. At that time 56.9 per cent of all miners with nystagmus were unemployed, while 37.2 per cent were in light employment on the surface and only 5.9 per cent were employed underground. The figures for Scotland were 83.3, 16.7 and 0 per cent, respectively. In fact, the other two case study coalfields also had relatively poor records as far as finding employment for partial compensation men was concerned (south Wales: 76.2 per cent out of work, 18.9 per cent employed on the surface and 4.9 per cent underground; the north-east of England: 81.8 per cent, 14.2 per cent and 4 per cent, respectively). The three coalfields were the three worst in Britain in this regard and stood far behind Lancashire and Cheshire, Derbyshire and Nottinghamshire, where between three-quarters and two-thirds of all sufferers of nystagmus were re-engaged. ${ }^{160}$

The case of Lanarkshire demonstrates the particular ways in which the implementation of the compensation legislation and the effects of the economic depression combined to create distinct problems for this group of disabled miners relative to miners with other impairments. By the terms of the legislation, 'nystagmic' miners were eligible for full or partial compensation, depending on the severity of their impairment, and a responsibility was placed on employers to provide light employment for those paid partial compensation. This was not a binding commitment, however, and employers, driven by self-interest or else concerned at perceived abuses, often looked to minimise any such responsibility. Employers in Lanarkshire were keen to avoid the employment of miners previously certified with nystagmus in underground work, since they found that a reoccurrence of the condition was quite possible, and so required that miners taken on should sign a declaration that they had not previously been certified with nystagmus. ${ }^{161}$ Thus, a great deal of hardship was caused to sufferers of nystagmus by the workings of the compensation system and the economic depression. The effects on the individuals concerned were significant: a judge at the Pontypridd County Court who heard the case of such a nystagmus sufferer in 1924 described such men as 'human derelicts', devoid of any hope of employment and treated poorly by a compensation system that could not meet the particular needs of individuals in a period of mass unemployment. ${ }^{162}$ Labour 
MP Jack Lawson remarks on the difficulty for men with nystagmus to find work, in his novel Under the Wheels (1934):

Harry Rew was the victim of nystagmus. 'Eyestagmus,' he calls it, unconscious that he had murdered a strictly scientific word, and at the same time given a lesson to medical science in scientific accuracy, for nystagmus is a disease of the eyes. Harry Rew had looked at coal so long that it made his eyes jump to look at it in the pit. If he had kept on looking at it he would have gone blind. So they gave him the 'caller's' job at bank. Lucky Harry! To-day he would have been given a few shillings a week, scrapped and lost among the statistics in the Minister of Mines' Report. But in those slow, unprogressive days he was given a job in the lamp cabin and a hammer to disturb the sleepers of Westburn. ${ }^{163}$

Lawson is clearly making a pointed remark about the contrast between the 'slow, unprogressive' past, where men nevertheless had opportunities that are no longer available now that so many are 'scrapped and lost among the statistics in the Minister of Mines' Report'. A positive view of the economic opportunities of the past is not uncommon in coalfields literature of the 1930s, when unemployment was so high and the writers want to emphasise the contrast between a fully employed, productive industrial area and an unproductive and declining industrial community. As in the example above, the inclusion of both older and disabled miners in the colliery workforce is used as a positive emblem of the idealised past, as compared to the present situation of high unemployment among all men, with almost no opportunities for older or disabled workers.

The presence of large numbers of disabled former miners in the ranks of the unemployed showed up in various social surveys on unemployment as greater attention was paid to the social characteristics of the unemployed and to the factors that led to joblessness in the first place. One survey carried out in Merthyr Tydfil in 1929, for example, found that 60 per cent of the unemployed men in the town were over the age of forty and noted that a large proportion of them were 'physically unfit. ${ }^{164}$ This seems to have been a particular problem in south Wales, relative to other coalfields. The social survey on unemployment conducted on behalf of the Pilgrim Trust in the 1930s, for example, found that a high proportion of the unemployed men in the Rhondda valleys sample suffered some form of physical impairment, largely as a result of nystagmus and 'silicosis'. Indeed, the report suggested both that the proportion was greater than might be expected in the working population generally and also that it was higher than was the case in other depressed areas. Indeed, another of the report's six case study areas was Crook, a mining community in Durham, and the report found that the physical condition of unemployed men was 'higher than elswhere' and that 'there is appreciably less of the physical disability 
(including industrial disease)' than was the case in the south Wales case study. ${ }^{165}$ This suggests, perhaps, that injury, disease and impairment were greater in south Wales than in other coalfields, which, given the higher accident rates and greater levels of occupational disease, is not wholly unreasonable. In addition, the higher level of disability revealed in the Rhondda relative to Crook might also have been due to the greater severity of the economic depression in south Wales - larger proportions of men were made unemployed and thereby became a problem as they came within sight of such investigations into long-term unemployment. Another factor was possibly the more settled industrial relations in the north-east of England, where the Arbitration Committee took some of the heat out of the issue of disabled miners and where more paternalistic employers continued to recognise their responsibilities to men injured in their employ.

The return of better conditions from the mid- to late 1930s, and especially the boost given to the industry with the build-up to, and the start of, the Second World War allowed greater numbers of older or disabled men to be reabsorbed into the industry. In an article on the south Wales coalfield in the Spectator published in 1945, for example, it was pointed out that unemployment had fallen from quarter of a million in 1933 to barely 15,000 by 1945 and that something like 10,000 individuals 'pronounced unfit for industrial work (some hadn't had a job for 15 years) have worked again as watchmen, sweepers-up, and on odd light jobs in factories. ${ }^{, 166}$ A great many of these worked outside the coal industry, of course, and certainly the Miners' Federation in south Wales noted the difficulty experienced in getting light employment for all those who required it. ${ }^{167}$ In addition, where it was not possible to find light employment for impaired former miners in the coal industry, Regional Controllers for the Ministry of Labour and National Service would place the individual in appropriate work in another industry. ${ }^{168}$ Nevertheless, labour shortages in the coal industry and the particular circumstances in the industry during war conditions were still responsible for a large part of this increase in employment for impaired individuals. A miners' leader in south Wales suggested that disabled men continued to be employed underground where previously they would have finished work: 'It's only the Essential Works Order which keeps a lot of those anthracite miners down the pit at all, he stated. ${ }^{169}$

A complicating factor in the employment of impaired miners in the war years, at least in south Wales, were changes to the compensation rules relative to pneumoconiosis. By the Coal Mining Industry (Pneumoconiosis) Compensation measure of 1943, those miners certified as suffering from the disease were stopped from working in industry. ${ }^{170}$ The effects on pneumoconiotic miners and their families were devastating. By end of 1945, 12,000 men in south Wales had been certified with the disease, and they were being certified at rate of 100 
a week by that time. Of this number, it was found that two-thirds were under fifty years of age and one quarter under forty and therefore still of working age and, quite likely, had families to support. ${ }^{171}$ This 'exodus' from the industry in mono-industrial communities in south Wales, where little alternative employment was available, caused considerable hardship and 'thousands of families' were forced to rely on compensation payments and unemployment benefits. ${ }^{172}$ Whereas something like 70 per cent of the certified pneumoconiotics found alternative employment outside the coal industry in the period of full employment during the latter years of the war, the figure was as low as 30-40 per cent in the late 1930s, and again by 1946 when Royal Ordinance Factories started closing. ${ }^{173}$ It is little wonder that one of these 'forgotten men' was able to characterise himself and his fellow sufferers as 'the living dead' of the coalfield, 'forgotten after a lifetime of service, 'sentenced to a hopeless, destitute and empty future. ${ }^{174}$

Nevertheless, a major change in the employment prospects of pneumoconiotic miners came with the passage of a measure in 1948 that allowed some certified men to return to work in the pits. This meant that 'seriously incapacitated' pneumoconiotics were permitted by the legislation to return to work in 'approved dust condition' on the surface, while men with lesser degrees of incapacitation were allowed to return to underground work. ${ }^{175}$ In the absence of alternative sources of employment, and perhaps for a number of cultural reasons relating to work in a solidaristic and mutualistic work environment, large numbers of impaired men returned to the coal industry in the late 1940s and 1950s, so that by 196020,000 pneumoconiotic miners were employed in the coal industry. $^{176}$

The miners' unions had campaigned for the nationalisation of the coal industry for many decades before this was finally achieved in 1947, and had always argued that a nationalised industry would replace the profit motive of private owners with a commitment both to the well-being of the nation and to the industry's workers. ${ }^{177}$ This change in ownership was also accompanied by a serious shortage of labour and an energy crisis which caused serious political difficulties to the Labour government, so that efforts were made to recruit as many workers into the industry as possible. ${ }^{178}$ More than that, while it was not perfect, trade union leaders nevertheless discerned a different atmosphere in the early months of nationalisation and a better prospect for disabled workers. Not only were there fewer disputes over compensation rights and payments to disabled workers, but there was also a greater commitment to finding employment for partially disabled men within the industry. The National Union of Mineworkers (NUM) was encouraged by the 'increasing efforts' of the National Coal Board (NCB) to find employment for such men and, indeed, the commitment at some collieries to find them as well-paid work as possible. The South Wales 
Area of the NUM, for example, noted the case of James Morgan, Gelli Colliery, Rhondda, who, having lost his sight as a result of an accident, was provided with training and given employment as a telephone operator. ${ }^{179}$ This commitment on the part of the NCB also extended to efforts to provide employment in ancillary industries connected to the coal industry, such as in the production of mining machinery. ${ }^{180}$

Nevertheless, this commitment on the part of the newly nationalised industry came up against the finite number of 'light employment' positions in the industry, as it always did, and many impaired miners continued to face unemployment as a result of their situation, much to the chagrin of trade union leaders. In 1947 an MP asked the Minster of Fuel and Power about the fate of unemployed ex-miners suffering minor impairments but fit for surface work, and was told rather vaguely that 'an effort [will be] made to find work for them of a character suitable to their conditions. He noted the rejection of many on medical grounds, there being 'considerable difficulty ... because in the main, these persons are suitable only for work on the surface and, as we are not in need of more workpeople for surface work, it is not easy to re-employ them. ${ }^{181}$

The effects of the wartime labour shortage and the dire need to increase production focused attention on the recruitment of young and fit men for face work, but part of this strategy involved the recruitment of 'older or unfit men' in order to free up 'on-cost' workers (i.e. underground workers who did not work at the face) to move to face work. A large proportion of the 'unfit' workers would have been former miners still being demobilised from the armed forces and, more importantly, former miners recruited from other industries: in 1947 alone, 41,000 ex-miners returned to the industry in answer to the desperate call for workers. ${ }^{182}$ More tellingly, the NCB changed its approach to former miners who had applied to return to the coal industry but who were rejected by colliery doctors as being unfit. Such men had claimed compensation for industrial disease or injuries previously but had commuted their claims for lump-sum settlements and, such was the desperate need for workers, the NCB advised its doctors to now accept them, despite continued impairments. $^{183}$

Therefore, the fortunes of disabled miners varied with those of the industry itself from 1880 to 1948 and with changes to the system of workmen's compensation. These broader factors determined the context in which such miners attempted to retain their employment after becoming impaired, and decided the labour market in which the value of their labour to employers increased or decreased over time. More generally, the extent and character of the labour of disabled workers, while not uncomplicated, demonstrates that while the coal industry created impairment on a massive scale, and in a variety of ways, it did 
not necessarily disable impaired workers from employment. Impaired workers were indeed marginalised in this particular area of the industrial economy, and faced economic hardship, prejudice and a loss of status, but they were not driven out of the industry completely and continued to constitute a prominent and visible presence in the workforce.

\section{Conclusion}

Disabled workers have largely been either left out of economic history or discussed only in terms of their exclusion. Histories of industrial Britain have largely ignored the interaction of impairment with the economic process of industrialisation, and the nuances of the economic position of disabled workers are very often overlooked. This period of late industrialisation, from the late nineteenth century through to the mid-twentieth century, was an eventful one for disabled people, as welfare innovations, fluctuations in economic circumstances and levels of employment, as well as changes in attitudes to accidents and safety, constantly changed the context in which disabled workers attempted to make their way in life. Furthermore, variations between regions and industries, and over time, ensured that there was no homogeneous experience of industrialisation for disabled people in the British coalfields, but that experiences were influenced by an array of factors and considerations. The experiences of disabled workers in the coal industry also demonstrate that, while their lives were subject to quite severe restrictions and difficulties, they were not wholly without agency and that they continued to aspire to a decent standard of living, a comfortable family life, and a degree of self-respect and consideration from others.

\section{Notes}

1 For example, see Michael Oliver, The Politics of Disablement: A Sociological Approach (Basingstoke: Palgrave Macmillan, 1990); Victor Finkelstein, Attitudes and Disabled People: Issues for Discussion (New York: International Exchange of Information in Rehabilitation, 1980).

2 N. K. Buxton, The Economic Development of the British Coal Industry from Industrial Revolution to the Present Day (London: Batsford Academic, 1978), p. 98.

3 John Benson, British Coalminers in the Nineteenth Century: A Social History (Dublin: Gill and Macmillan, 1980).

4 Benson, British Coalminers in the Nineteenth Century, p. 7.

5 Benson, British Coalminers in the Nineteenth Century, pp. 9-12.

6 Benson, British Coalminers in the Nineteenth Century, pp. 216-17.

7 Benson, British Coalminers in the Nineteenth Century, pp. 17, 216-17.

8 Buxton, The Economic Development of the British Coal Industry, p. 85. 
9 Benson, British Coalminers in the Nineteenth Century, pp. 22-5.

10 Barry Supple, The History of the British Coal Industry, Volume 4. 1913-1946: The Political Economy of Decline (Oxford: Clarendon Press, 1987), p. 10.

11 John Stevenson and Chris Cook, Britain in the Depression: Society and Politics 1929-39 (Harlow: Longman Group, 1994 edition), pp. 66-70; Report of the Commissioner for the Special Areas in England and Wales [Cmd. 5896], 1938-39, xii, pp. 95-6.

12 Sidney Pollard, The Development of the British Economy 1914-1990 (London: Arnold, 1997 edition), pp. 35-6, 49-52, 140-2, 168-9.

13 An overview of coalfields literature in the period $1880-1948$ is given in Chapter 6.

14 Such as Joseph Skipsey, or Thomas 'Tommy' Armstrong.

15 There were a number of Methodist ministers who were also novelists who wrote about the coalfields, such as Ramsay Guthrie (pseudonym Rev. J. G. Bowran, Primitive Methodist), Hugh Gilmore (Primitive Methodist), Harry Lindsay (pseudonym of Henry Lindsay Hudson, Wesleyan Methodist), Samuel Horton (Primitive Methodist), W. M Patterson (Primitive Methodist) and John Thomas (Calvinist and later Independent, and Welsh-language novelist).

16 For example, Richard Cope Morgan's biography The Life of Richard Weaver, the Converted Collier (London: Morgan \& Chase, 1861), Howard Peases's The WhiteFaced Priest and Other Northumbrian Episodes (London: Gay \& Bird, 1896) and Owd Mo's From Coal-Pit to Joyful News Mission (Rochdale: Joyful New Book Depot, c.1890).

17 For example, Thomas Mitchell, W. A. Hammond, Joseph Johnson and Charles H. Kelly.

18 For example, Independent Labour Party Publications, Lawrence and Wishart (initially associated with the Communist Party), Gollancz, and Michael Joseph Ltd.

19 Jack Jones, Unfinished Journey (London: Hamish Hamilton, 1938), p. 282.

20 Jones, Unfinished Journey, p. 291.

21 Roy A. Church, The History of the British Coal Industry Volume 3: 1830-1913: Victorian Pre-Eminence (Oxford: Clarendon Press, 1986), p. 209.

22 The following treatment of mining occupations is dependent on Benson, British Coalminers in the Nineteenth Century, pp. 28-63; Church, The History of the British Coal Industry, Volume 3, pp. 201-15; information extracted from the Reports of the Inspectors of (Coal) Mines, 1894, [C. 7667], 1895, xxii, presented on 'Mining Occupations', Durham Mining Museum website, http://www.dmm.org.uk/ educate/mineocc.htm, accessed 21 October 2016; and James Barrowman, Glossary of Scotch Mining Terms (Hamilton, 1886), available at Scottish Mining Website, www.scottishmining.co.uk/Indexes/Barrowman.html, accessed 21 October 2016.

23 Martin Daunton, 'Down the Pit: Work in the Great Northern and South Wales Coalfields, 1870-1914', Economic History Review, 34:4 (1981), p. 585; Church, The History of the British Coal Industry, Volume 3, pp. 211-13. 
24 Daunton, 'Down the Pit', p. 585; Church, The History of the British Coal Industry, Volume 3, pp. 207-8; Alan Campbell, The Scottish Miners, 1874-1939. Volume One: Industry, Work and Community (Aldershot: Ashgate, 2000), pp. 78-9.

25 Benson, British Coalminers in the Nineteenth Century, p. 29.

26 Tom Hanlin, Yesterday Will Return (New York: The Viking Press, 1946), p. 78.

27 N. K. Buxton, The Economic Development of the British Coal Industry from Industrial Revolution to the Present Day (London: Batsford Academic, 1978), pp. 109, 112; David Greasley, 'Fifty Years of Coal-Mining Productivity: The Record of the British Coal Industry before 1939', Journal of Economic History, 50:4 (1990), p. 883.

28 Greasley, 'Fifty Years of Coal-Mining Productivity', p. 896.

29 Buxton, The Economic Development of the British Coal Industry, p. 114-15.

30 Buxton, The Economic Development of the British Coal Industry, p. 115.

31 Supple, The History of the British Coal Industry, Volume 4. 1913-1946: The Political Economy of Decline, p. 27.

32 Report of the Royal Commission on the Coal Industry (1925) (London, HMSO, 1926), p. 192.

33 News Chronicle, 18 February 1936.

34 B. L. Coombes, These Poor Hands: The Autobiography of a Miner Working in South Wales, with an Introduction by Bill Jones and Chris Williams (Cardiff: University of Wales Press, 2002), p. 74.

35 Coombes, These Poor Hands, p. 82.

36 Coombes, These Poor Hands, p. 82.

37 Coombes, These Poor Hands, p. 82.

38 Coombes, These Poor Hands, p. 84.

39 Coombes, These Poor Hands, p. 84.

40 Lewis Jones, Cwmardy (London: Lawrence \& Wishart, 1937), pp. 397-8; Sid Chaplin, The Thin Seam (London: Phoenix House, 1950), pp. 141-9.

41 Gwyn Jones, Times Like These (London: Victor Gollancz, 1979 [1936]), p. 287.

42 Chaplin, The Thin Seam, p. 89.

43 See pages 35-6.

44 Chaplin, The Thin Seam, p. 92.

45 Daunton, 'Down the Pit'.

46 South Wales Worker, 30 May 1914, p. 6.

47 'Cavil' was the word used in the north-east of England for the working area allocated to hewers underground and drawn for by lots.

48 John Swan, The Mad Miner (London: Houghton Publishing Co, 1933), pp. 171-2.

49 See, for example, Miners' Federation of Great Britain, Annual Conference held at the Central Hall, Bath Street, Glasgow, on Tuesday, July 24th, 1917, and following days, pp. 43-6, 87. In this instance, the resolution was moved by a south Wales delegate and seconded by a colleague from Scotland.

50 Benson, British Coalminers in the Nineteenth Century, pp. 55-6.

51 Quoted in Campbell, The Scottish Miners, 1874-1939. Volume One, p. 82.

52 Benson, British Coalminers in the Nineteenth Century, pp. 58-9; Campbell, The Scottish Miners, 1874-1939. Volume One, pp. 82-3. 
53 B. L. Coombes, Those Clouded Hills (London: Cobbett Publishing Co., 1944), p. 27, also p. 29; see also Benson, British Coalminers in the Nineteenth Century, p. 59.

54 Daunton, 'Down the Pit', p. 587; see also Benson, British Coalminers in the Nineteenth Century, p. 56.

55 Daunton, 'Down the Pit', pp. 587-8.

56 Church, The History of the British Coal Industry, Volume 3, p. 257.

57 Benson, British Coalminers in the Nineteenth Century, p. 56; Campbell, The Scottish Miners, 1874-1939. Volume One, p. 83.

58 Daunton, 'Down the Pit', p. 589.

59 M. W. Kirby, The British Coalmining Industry, 1870-1946: A Political and Economic History (London: Macmillan, 1977), pp. 68, 24.

60 See for example, The Eight Hours Movement (Coal Mines): Proceedings at a Joint Conference of Representative Coal Owners and the Miners' Federation of Great Britain held at the Westminster Palace Hotel, London, S.W., on the 21st Jnuary, and the 11th February, 1891 (1891), esp. pp. 10-11, 42-3.

61 Mesur yr wyth awr / The Eight Hours Bill (s.l., s.n., between 1894 and 1899).

62 Colliery Guardian, 30 July 1926; see also the letter on this matter in The Times, 3 July 1926.

63 Daunton, 'Down the Pit', pp. 588-9.

64 Miners' Federation of Great Britain, Annual Conference held at the Central Hall, Central Hall, Westminster, London, on Thursday and Friday, November 7 th and 8th, 1918, p. 73.

65 V. L. Allen, The Militancy of British Miners (Shipley: Moor Press, 1981), p. 74. Elizabeth Andrews, the Labour Party's women organiser for Wales, also noted in 1923 how 'it is not only the men who are employed by the Mineowners, but their wives are also employed (without pay) to clear up the dirt in the homes that ought to have been left at the pit top'; Colliery Workers Magazine, September 1923, in Elizabeth Andrews, A Woman's Work is Never Done and Political Articles, edited by Ursula Masson (Dinas Powys: Honno, 2006), p. 65.

66 Andrews, A Woman's Work is Never Done, p. 71.

67 Church, The History of the British Coal Industry, Volume 3, pp. 608-9.

68 See, for example, Report of the Royal Commission on the Housing of the Industrial Population of Scotland, Cd. 8731 (Edinburgh: HMSO, 1917), xiv. Indeed, this Royal Commission was largely initiated as a result of political pressure from the Scottish Miners' Federation and conducted careful investigation into housing conditions in the country's mining regions.

69 M. R. Haines, 'Fertility, Nuptiality, and Occupation: A Study of Coal Mining Populations and Regions in England and Wales in the Mid-Nineteenth Century', Journal of Interdisciplinary History, 8:2 (1977), pp. 259-62; also Valerie Gordon Hall, 'Contrasting Female Identities: Women in Coal Mining Communities in Northumberland, England, 1900-1939', Journal of Women's History, 13:2 (2001), pp. 110-11; Benson, British Coalminers in the Nineteenth Century, p. 121.

70 On lodgers, see Dot Jones, 'Counting the Cost of Coal: Women's Lives in the Rhondda, 1881-1911', in Angela V. John (ed.), Our Mothers' Land: Chapters 
in Welsh Women's History 1830-1939 (Cardiff: University of Wales Press, 1991), pp. 119-20; Church, The History of the British Coal Industry, Volume 3, p. 602.

71 Church, The History of the British Coal Industry, Volume 3, p. 608.

72 James C. Welsh, The King and the Miner: A Contrast (London: ILP Publication Department, 1923), p. 6.

73 Welsh, The King and the Miner, p. 6.

74 Jack Jones, Bidden to the Feast (London: Corgi Books 1968 [1938]), p. 51. This novel was set mid- to late nineteenth century.

75 This woman also suffered anaemia, 'whiteleg' (i.e. phlegmasia alba dolens, a form of deep vein thrombosis with sympotoms of edema, pain and a characteristic white colouration of the leg), constipation and piles, bad dental caries, headaches, palpitations, faintness, and experienced a period of facial paralysis; Margery Spring Rice, Working-Class Wives: Their Health and Condition (London: Virago, 1981 edition; originally published in 1939), p. 122.

76 Jones, 'Counting the Cost of Coal', p. 116.

77 W. John Morgan, 'The Miners' Welfare Fund in Britain 1920-1952', Social Policy \& Administration, 24:3 (1990), p. 205.

78 Dame Janet Campbell, 'Introduction', in Spring Rice, Working-Class Wives, p. $x v$.

79 Gordon Hall, 'Contrasting Female Identities', p. 112.

80 Rhys Davies, 'Nightgown', in Collected Stories: Volume 1, edited by Meic Stephens (Llandysul: Gomer 1996), p. 238.

81 For portayals of this process, see Margaret Llewleyn Davies (ed.), Life as We Have Known It (London: Virago, 1977 [1931]), pp. 67-72; Coombes, These Poor Hands, p. 41.

82 Coal Industry Commission, Vol. II: Reports and Minutes of Evidence on the Second Stage of the Inquiry, Cmd. 360 (London: HMSO, 1919), xii, p. 1019.

83 Andrews, A Woman's Work Is Never Done, p. 66.

84 Jones, 'Counting the Cost of Coal', p. 109.

85 Rhondda Socialist, 11 April 1912, in Jane Aaron and Ursula Masson (eds), The Very Salt of Life: Welsh Women's Political Writings from Chartism to Suffrage (Dinas Powys: Honno, 2007), pp. 220-2.

86 Spring Rice, Working-Class Wives, pp. 96-7, 108.

87 Spring Rice, Working-Class Wives, p. 122.

88 Coal Industry Commission, Vol. II: Reports and Minutes of Evidence, p. 1020; see also the testimony of Agnes Brown from Bellshill, Lanarkshire (pp. 1022-25).

89 H.M. Chief Inspector of Mines, Mines and Quarries: General Report, with Statistics, for 1920, Part II. Labour, 1921 (239), xli, p. 61.

90 B. L. Coombes, Miners Day (Harmondsworth: Penguin Books, 1945), p. 8.

91 Report of the Royal Commission on Safety in Coal Mines, Cmd. 5890 (London: HMSO, 1938), xiii, p. 65. 
92 H.M. Chief Inspector of Mines, Mines and Quarries: Part II. Labour, p. 61; H.M. Chief Inspector of Mines, Mines and Quarries: General Report, with Statistics, for 1920, Part I. Divisional Statistics, 1921 (115), xli, p. 17.

93 For example, flood disasters are included in Scotland-set literature such as James C. Welsh's The Underworld, The Story of Robert Sinclair, Miner (London: Herbert Jenkins, 1920) and Tom Hanlin's Miracle at Cardenrigg (London: Random House, 1949); also in Durham-set novels Harold Heslop's The Gate of a Strange Field (London: D. Appleton and Company, 1929) and A. J. Cronin's The Stars Look Down (London: Gollancz, 1935).

94 For example, gas explosions, reports of unsafe levels of gas and survivors with burn-scarred bodies are variously portrayed in Wales-set literature including: Harry Lindsay's Rhoda Roberts (London: Chatto \& Windus, 1895), Joseph Keating's Son of Judith (London: G. Allen, 1900), Allen Raine's A Welsh Witch (London: Hutchinson \& Co., 1902), Ellis Lloyd's Scarlet Nest (London: Hodder \& Stoughton, 1919), Lewis Jones's Cwmardy (London: Lawrence \& Wishart, 1937), Jack Jones's Black Parade (London: Faber \& Faber, 1935), Susan Buchan's The Scent of Water (London: Hodder \& Stoughton, 1937) and Glyn Jones's 'Explosion' in The Water Music (London: G. Routledge \& Sons, 1944).

95 Harold Heslop, Last Cage Down (London: Lawrence Wishart Books, 1984 [1935]); A. J. Cronin, The Citadel (London: Vista, 1996 [1937]).

96 H.M. Chief Inspector of Mines, Mines and Quarries: Part II. Labour, p. 61.

97 Frank Shufflebotham, 'The Hygienic Aspect of the Coal-Mining Industry in the United Kingdom: Lecture V. Beat Hand, Knee, Elbow and Buttock', British Medical Jounal, 4 April 1914, p. 755.

98 Statistics of Compensation and Proceedings under the Workmen's Compensation Acts, and the Employers' Liability Act, 1880, in Great Britain, 1908-38 (annual series).

99 Shufflebotham, 'The Hygienic Aspect of the Coal-Mining Industry in the United Kingdom', p. 756.

100 T. Lister Llewellyn, 'A Lecture on Miners' Nystagmus', British Medical Journal, 28 June 1913, p. 1359; see also, Report of the Royal Commission on the Coal Industry (1925) (London, HMSO, 1926), p. 195.

101 B. L. Coombes, I Am a Miner (London: Fact, 1939), pp. 72-3.

102 An official report claimed in the late 1930s that "Work is the salvation of "nystagmic" workmen, and surface employment plays as great a role in the treatment of the disease as underground work does in its production'; Report of the Departmental Committee on Certain Questions Arising under the Workmen's Compensation Acts, Cmd. 5657, (London: HMSO, 1938), xv, p. 4.

103 Statistics of compensation and proceedings under the Workmen's Compensation Acts, and the Employers' Liability Act, 1880, in Great Britain, 1908-38 (annual series).

104 See, for example, the fall in certified cases recorded in the Lanarkshire coalfield from 1931 to 1932; Report by the Departmental Committee on Certain Questions Arising under the Workmen's Compensation Acts, pp. 6, 45-6. 
105 Llewellyn, 'A Lecture on Miners' Nystagmus', p. 1360.

106 Arthur McIvor and Ronald Johnston, Miners' Lung: A History of Dust Disease in British Coal Mining (Aldershot: Ashgate, 2007), p. 2.

107 In addition to McIvor and Johnston, Miners' Lung, see Mark W. Bufton and Joseph Melling, “'A Mere Matter of Rock”: Organized Labour, Scientific Evidence and British Government Schemes for Compensation of Silicosis and Pneumoconiosis among Coalminers, 1926-1940', Medical History, 49:2 (2005), pp. 155-78; Mark W. Bufton and Joseph Melling, 'Coming up for Air: Experts, Employers, and Workers in Campaigns to Compensate Silicosis Sufferers in Britain, 1918-1939', Social History of Medicine, 18:1 (2005), pp. 63-86.

108 NUM (South Wales Area) Executive Council Annual Report, 1948-9, p. 93.

109 On the incidence of pneumoconiosis among coal-trimmers, see McIvor and Johnston, Miners' Lung, p. 85.

110 On the variable risks of dust exposure in different parts of the underground workings, see Enid M. Williams, The Health of Old and Retired Coalminers in South Wales (Cardiff: University of Wales Press Board, 1933), pp. 17-20.

111 McIvor and Johnston, Miners' Lung, p. 56.

112 See Ben Curtis and Steven Thompson, "'This Is the Country of Premature Old Men”: Ageing and Aged Miners in the South Wales Coalfield, c.1880-1947', Cultural and Social History, 12:4 (2015), pp. 587-606.

113 Williams, The Health of Old and Retired Coalminers, p. 19.

114 Williams, The Health of Old and Retired Coalminers, pp. 19-20.

115 Williams, The Health of Old and Retired Coalminers, p. 45.

116 Janet M. Campbell, Maternal Mortality (London: HMSO, 1924), p. xvi.

117 Standing Joint Committee of Industrial Women's Organisations, Report on "Protect the Nation's Mothers" (London: Labour Party, 1936) presented to the National Conference of Labour Women, Sheffield, May 1935, p. 6.

118 Ministry of Health, Report on an Investigation into Maternal Mortality, Cmd. 5422, 1936-37, xi, p. 12.

119 On the methodology utilised, see Spring Rice, Working-Class Wives, pp. 21-7.

120 Spring Rice, Working-Class Wives, p. 20.

121 Spring Rice, Working-Class Wives, p. 37.

122 Scottish Board of Health, Report of the Scottish Departmental Committee on Puerperal Morbidity and Mortality (Edinburgh: HMSO, 1924), p. 10.

123 Spring Rice, Working-Class Wives, pp. 85-6; interestingly, Spring Rice maintained that the women who faced these difficulties but who still maintained a positive attitude and continued to cope with their domestic responsibilities most effectively were more numerous in the north of England and Scotland than in the 'south'; Spring Rice, Working-Class Wives, p. 85.

124 Spring Rice, Working-Class Wives, p. 164.

125 Spring Rice, Working-Class Wives, p. 53.

126 Evening Telegraph, 24 February 1889. 
127 Reports of W. Walker, H.M. Inspector of Mines for the Scotland Division, p. 37 in Reports of the Inspectors of Mines for the Year 1913.

128 Henry Norman Barnett, Accidental Injuries to Workmen, with Reference to Workmen's Compensation Act, 1906. With Article on Injuries to the Organs of Special Sense (London: Rebman, 1909), p. 33.

129 On the significant role of the First World War, see Mike Mantin, 'Coalmining and the National Scheme for Disabled Ex-Servicemen after the First World War', Social History, $41: 2$ (2016), pp. 155-70; Joanna Bourke, Dismembering the Male: Men's Bodies, Britain, and the Great War (London: Reaktion Books, 1996).

130 National Archives of Scotland (hereafter NAS), CB 19/1, 14704/12, Scottish Coal Workers' Compensation Scheme, Directors' Minute Books, 1912-1914, James Dalrymple v The Fife Coal Company Ltd.

131 NAS, CB 19/1, 2056/12, Scottish Workers' Compensation Scheme, Directors' Minute Books, 1912-1914, Charles Robertson v The Fife Coal Co. Ltd.

132 Jeffrey Grenfell-Hill (ed.) Growing up in Wales: Collected Memories of Childhood in Wales 1895-1939 (Llandysul: Gomer, 1996), p. 50.

133 Grenfell-Hill, Growing Up in Wales, p. 52.

134 NAS, CB 19/1, F.2561/14, Scottish Workers' Compensation Scheme, Directors' Minute Books, 1912-1914, Kenneth Sparling v The Fife Coal Co. Ltd.

135 Durham County Record Office (hereafter DCRO), C47, Durham Miners' Association Compensation Department, Minutes of the Arbitration Committee, January to December 1925, 21 December 1925.

136 DCRO, C47, Durham Miners' Association Compensation Department, Minutes of the Arbitration Committee, January to December 1925, 29 December 1925 .

137 Ashington Coal Company in the north-east of England consulted a doctor over the appropriate form of light work for disabled miners on their return to work; Griselda Carr, Pit Women: Coal Communities in Northern England in the Early Twentieth Century (London: Merlin Press, 2001), p. 63.

138 Glamorgan Archives, DPD/2/5/6/160, Powell Duffryn Collection Papers concerning compensation, 1925-1926, 14 December 1926.

139 Colliery Guardian, 27 August 1926.

140 Colliery Guardian, 27 August 1926.

141 NAS, CB 19/4, Scottish Coal Workers' Compensation Scheme, Directors' Minute Books, 1919-1921, F831/18 Hetherington v The Fife Coal Co. Ltd.

142 Coombes, These Poor Hands, pp. 63-4.

143 This is exactly how workmen's compensation legislation worked in other countries too; see Sarah F. Rose, No Right to be Idle: The Invention of Disability, 1840s-1930s (Chapel Hill: University of North Carolina Press, 2017).

144 Cardiff Times, 10 December 1898, p. 1. Indeed, the south Wales miners' leader William Abraham ('Mabon') anticipated that this would be the immediate outcome of the legislation; Cardiff Times, 22 May 1897, p. 1.

145 Evening Express, 18 November 1898, p. 2. 
146 DCRO, D/DCOMPA 235, Durham Coal Owners' Mutual Protection Association, Agreements with Durham Miners' Association concerning compensation for non-fatal accidents, 29 June 1898; see also Departmental Committee on Workmen's Compensation, Report by the Departmental Committee Appointed to Inquire into the System of Compensation for Injuries to Workmen, Cmd. 816 (London: HMSO, 1920), xxvi, p. 57.

147 DCRO, D/X 1005/21, Correspondence to let aged or infirm men go at Chopwell Colliery, 10 September 1912.

148 Angela V. John. By the Sweat of Their Brow (London: Croom Helm, 1980), p. 200.

149 J. M. Winter, 'Britain's "Lost Generation” of the First World War', Population Studies, 31:3 (1977), p. 452; Mike Mantin, 'Coalmining and the National Scheme for Disabled Ex-Servicemen after the First World War', Social History, 41:2 (2016), p. 158.

150 Monmouth Guardian, 5 November 1915, p. 3. It was often suggested that older men, which might have included men with disabilities, might be taken on to release other men for the front; see, for example, Llais Llafur, 1 April 1916, p. 1; Cambrian Daily Leader, 7 March 1916, p. 6.

151 Selection criteria were used to 'comb out' eligible men from the workforce for conscription into the army.

152 Miners' Federation of Great Britain, Recruiting of Miners. Deputation of the Executive Committee of the Miners' Federation of Great Britain to the Right Hon. Sir George Cave, K.C., M.P. (Secretary of State for the Home Department), Thursday, February 1st, 1917 (Manchester, 1917), pp. 4-9.

153 Miners' Federation of Great Britain, Recruiting of Miners, pp. 26, 28.

154 Miners' Federation of Great Britain, Special Conference held at the Central Hall, Westminster, London, on Thursday and Friday, April 19th and 20th, 1917, p. 12.

155 Miners' Federation of Great Britain, Special Conference held at the Central Hall, Westminster, London, on Wednesday, June 20th 1917, p. 27.

156 Miners' Federation of Great Britain, Special Conference held at the Westminster Palace Hotel, London, on Tuesday and Wednesday, May 9th and 10th, 1916, pp. 17-18.

157 Report of the Departmental Committee on Certain Questions Arising under the Workmen's Compensation Acts, Cmd. 5657 (London: HMSO, 1938), xv, p. 20.

158 Hansard, 12 May 1938.

159 Report by the Departmental Committee on Certain Questions Arising under the Workmen's Compensation Acts, p. 6.

160 Report by the Departmental Committee on Certain Questions Arising under the Workmen's Compensation Acts, p. 48.

161 Report by the Departmental Committee on Certain Questions Arising under the Workmen's Compensation Acts, pp. 6-8, 21-3. The same practices were employed in south Wales; South Wales Miners' Federation, Annual Report of Executive Council, 1935-1936, pp. 34-5. 
162 Western Mail, 21 June 1924, p. 9.

163 Jack Lawson, Under the Wheels (London: Hodder \& Stoughton, 1934), p. 26.

164 National Library of Wales, Thomas Jones C. H. papers, John Davies and David E. Evans, 'Report on Merthyr Tydfil', 11 July 1929, p. 5.

165 Men Without Work: A Report made to the Pilgrim Trust (Cambridge: Cambridge University Press, 1938), pp. 66-7, 72, 81, 424.

166 The Spectator, 23 February 1945, p. 7.

167 South Wales Miners' Federation, Report of Compensation Department, 1943-1944, p. 47.

168 Miners' Federation of Great Britain, Minutes of the Executive Committee Meeting, 8 June 1944.

169 The Spectator, 23 February 1945, p. 7.

170 McIvor and Johnston, Miners' Lung, pp. 86-7.

171 C. M. Fletcher, 'Pneumoconiosis of Coal-Miners', British Medical Journal, 5 June 1948, p. 1065.

172 'Report of Compensation Department, 1945-1946', in NUM South Wales Area Council Annual Report, 1945-1946, p. 61.

173 Fletcher, 'Pneumoconiosis of Coal-Miners', p. 1066.

174 The Miner, 1:4 (January, 1945), p. 14.

175 McIvor and Johnston, Miners' Lung, pp. 87-8.

176 McIvor and Johnston, Miners' Lung, pp. 148-9.

177 For an example of the variety of arguments made in favour of nationalisation, see Independent Labour Party, The Mineowners in the Dock: A Summary of the Evidence Given before the Coal Industry Commission (London: Independent Labour Party, 1919).

178 National Coal Board, Annual Report and Statement of Accounts for the Year Ended 31st December 1947, pp. 1-5.

179 NUM South Wales Area Council Annual Report, 1948-1949, p. 81.

180 Fletcher, 'Pneumoconiosis of Coal-Miners', p. 1067.

181 Hansard, 1 May 1947.

182 National Coal Board, Annual Report and Statement of Accounts for the Year Ended 31st December 1947, pp. 46-7.

183 Ministry of Labour and National Service, Report for the Year 1948, Cmd. 7822, 1948-49, xvii, p. 32. 